\title{
ASSESSMENT OF FLASH FLOOD "APRIL 2018" AND ITS EFFECT ON WADI DEGLA AND WADI EL-HALAZOUNI - EAST CAIRO - EGYPT
}

\author{
Nahla A. Morad ${ }^{1}$, Nemaat A. Youssef ${ }^{2}$, Sawsan M.M. Ibrahem ${ }^{{ }^{*}}$ \\ ${ }^{1}$ Department of Hydrology, Desert Research Center, El-Matareya, \\ Cairo, Egypt \\ ${ }^{2}$ Department of Geology, Desert Research Center, El-Matareya, Cairo, \\ Egypt \\ *E-mail: sawsanmoselhy@yahoo.com
}

ntegrated Geographic Information System and Remote
Sensing technology with an improved Soil
Conservation Service curve number model were applied to analyze and assess the characteristics and impacts of the rainfall storm occurred at April 2018 in East Cairo. In addition, evaluating the effects of land use changes and urbanization on surface runoff is one of the main objectives in this study. Wadi Degla $\left(195 \mathrm{~km}^{2}\right)$ and Wadi El-Halazouni (48 $\mathrm{km}^{2}$ ), were selected for this study. The morphometric analysis revealed that, Wadi Degla and Wadi El-Halazouni have elongated shape and lower peak runoff of longer duration over its area. The return period calculations revealed that the storm of April 2018 may be happened only every 67 years. The HECHMS software is applied to estimate the peak discharge and runoff volume for two different cases (rural case at 1984 and urban case at 2018). The results revealed that the runoff volume of Wadi El-Halazouni attains about $252.3 \times 10^{3} \mathrm{~m}^{3}$ and $416.7 \times 10^{3} \mathrm{~m}^{3}$ for rural case and urban case, respectively. For Wadi Degla the runoff volume in rural case was estimated as $1434.6 \times 10^{3} \mathrm{~m}^{3}$, while in urban case it is reached about 1570.4 $\mathrm{x} 10^{3} \mathrm{~m}^{3}$ indicating more runoff volume of urban case than the rural case. It is recommended, in Wadi El-Halazouni catchment, to construct a rainwater drainage system to collect the rainfall water and use it for irrigation. In Wadi Degla, construction of storage dams along its main trunk is necessary to protect the urban area in the Delta of the wadi from the occasionally flash flood risk.

Keywords: rural and urban areas, rainfall-runoff relationship, Remote Sensing, Geographic Information Systems (GIS), Hydrological Model 
Rainfall-runoff modeling is becoming very important for the protection of the urban areas from flood risks and damages, especially in the new communities. To evaluate the flood risk of the basin systems, the rainfall and runoff data are the most essential hydrological elements. Therefore, when there is a scarcity of measured hydrological data, one has to find out some alternative methods to address this situation. One of these alternatives is the using of the topographic and geomorphologic features of the wadi to develop flood risk maps (Şen et al., 2012). The integration between GIS and basin physiographic features to assess flash flood risk has been continually upgraded and widespread since beginning of $21^{\text {st }}$ century, as a result of the increased availability of spatial databases and GIS software (Zerger and Smith, 2003). Climate change was noticeable in the study area during the last decades. Climate change is change in weather pattern for a significantly long period, one of the major impacts of climate change is variation in rainfall pattern which directly or indirectly affects the regional water resources which are rainfed / recharged (Udayashankara et al., 2016).

\section{Location of the Study Area}

The study area lies in the eastern part of Cairo between latitudes $29^{\circ} 50^{\prime} 00^{\prime \prime} \mathrm{N} \& 30^{\circ} 03^{\prime} 00^{\prime \prime} \mathrm{N}$ and longitudes $31^{\circ} 10^{\prime} 00^{\prime \prime} \mathrm{E} \& 31^{\circ} 45^{\prime} 00^{\prime \prime} \mathrm{E}$. It covers an area of about $1548 \mathrm{~km}^{2}$ and encompassing Wadi Degla and Wadi El-Halazouni. In the last three decades, the study area was subjected to intensive new settlements namely New Cairo City and New Maadi, which needs establishing of large network of asphaltic roads to facilitate the transportation in these new communities (Fig. 1).

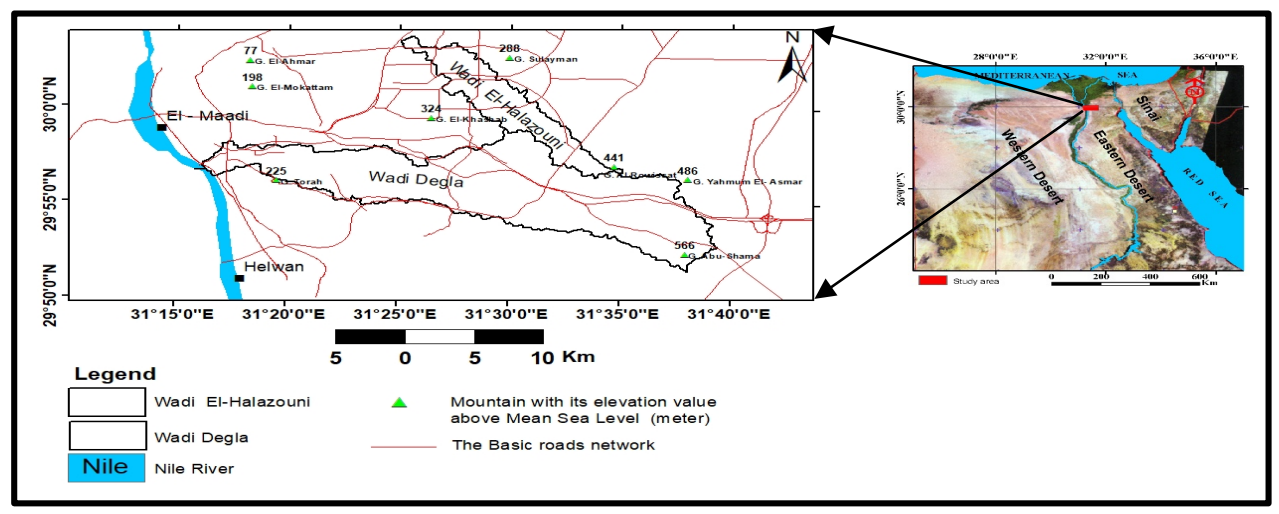

Fig. (1). Location map of the study area. 
The study area lies within the arid to hyper-arid belt in Egypt. According to the Egyptian Metrological Authority (EMA, 1949-2018) at Cairo Airport Station $\left(30^{\circ} 07^{\prime} 48^{\prime \prime} \mathrm{N} \& 31^{\circ} 24^{\prime} 00^{\prime \prime} \mathrm{E}\right)$, the mean maximum temperature is recorded in June $\left(34.7^{\circ} \mathrm{C}\right)$, while the mean minimum temperature is recorded in January $\left(9^{\circ} \mathrm{C}\right)$. The relative humidity ranges between $40 \%$ and $56 \%$. Generally, the rainfall precipitates in winter season with a mean annual rainfall of about $23 \mathrm{~mm}$.

The area of study was subjected to a heavy rainfall storm causing flash flood at 24-25 April 2018 with values 31.3 and $33.57 \mathrm{~mm}$ in Wadi Degla and Wadi El-Halazouni, respectively. This flood causes severe damage in the infrastructure of the new settlements, especially in Wadi Degla $\left(194.95 \mathrm{~km}^{2}\right)$ and Wadi El-Halazouni $\left(47.92 \mathrm{~km}^{2}\right)$, where the runoff water covered most of the asphaltic roads and many vehicles were immersed in the flood water.

The main objective of the present work is to analyze and assess the possible effect of the flash flood of the event of April 2018. Wadi Degla has been used for many years for quarrying to provide building stone and cement, with the consequent deterioration in environment and habitat. Since 1999, it has been declared as Protectorate area by the Egyptian Government in order to maintain its fragile ecosystem. New settlements have been established since 1984 until now, in the Delta of Wadi Degla and Wadi ElHalzouni. This urbanization brings a range of physical and biochemical changes to hydrological system and processes.

\section{Geomorphological and Geological Settings}

According to the Digital Elevations Model (DEM) of the study area (Fig. 2), the topographic maps scale 1:50,000 \& 1:25,000 and the geologic maps scale 1:500,000, a geomorphological map for the study area was constructed (Fig. 3), that showing three geomorphological units:

- Nile flood plain; is formed by a tectonic depression, with an area of about $355 \mathrm{~km}^{2}$. This unit is almost flat having elevations less than 50 $\mathrm{m}$ above mean sea level. The delta of Wadi Degla represents a part of this unit.

- Piedmont plain; is a transition zone between the Nile flood plain and the plateau units. It has an area of about $500 \mathrm{~km}^{2}$ with an existing elevation ranges from 50 to $350 \mathrm{~m}$ above mean sea level.

- Structural plateau; consists mainly of limestone and is dissected by groups of normal faults. It has an area of about $700 \mathrm{~km}^{2}$ with elevation values ranging between 250 and $615 \mathrm{~m}$ above mean sea level. This unit represents the upstream of the different Wadis, where it is characterized by several high elevated mountains such as G. Sulayman $(+288 \mathrm{~m})$, G. Rowissat $(+441 \mathrm{~m})$, G. Abu-Shama $(+566 \mathrm{~m})$ and $\mathrm{G}$. Yahmum El-Asmar (+486 m). 
Geologically, the study area has been studied by many authors: Barron (1907), Shukri (1954), Said (1962, 1990), Moustafa and Abd-Allah (1991) and UNDP et al. (2008). Geological maps titled Cairo and Beni Suef scale 1: 500,000 (CONOCO, 1987) are used as a guide to define the existed sedimentary exposures with their abbreviations and the geological structures in the study area. The exposed rock units are arranged from old to young as follows (Fig. 4):

\section{Tertiary deposits}

- Eocene; is represented by Middle Eocene and Upper Eocene. The Middle Eocene rocks is the oldest exposed rock outcrop at the southern part of Wadi Degla and represented by Mokattam Group (Tem), which is predominantly consists of Observatory Formation that consists of white to yellowish white, marly and chalky limestone intercalated with hard, grey dolomitic limestone bands. The Upper Eocene is represented by Maadi Formation (Ted) covering a considerable area of Wadi Degla. According to Said (1990), the Maadi sediments are of more clastic nature than that of the underlying Mokattam sediments where, they are made up mostly of shale with intercalated limestone. The shale is grayish green, highly calcareous, fossiliferous and partially sandy. The limestone is light to dark brown, highly argillaceous, medium hard and locally limonitic. According to Moustafa and Abd-Allah (1991), claystone and marls characterize the Upper Eocene east of Cairo city.

- Oligocene rocks; is overlying the Upper Eocene rocks and comprises the Gebel Ahmar Formation (Toa), which dominates a wide area of the New Cairo City, typically in the Petrified Forest. It is made up of sandstones and gravels with silicified pipes and tree trunks. A typical example of the sands and gravels of the Cairo-Suez district is in Gebel Ahmar, to the east of Cairo, made famous as described by Barron (1907) and Shukri (1954). The Gebel Ahmar sands are vividly colored, cross bedded and coarse-grained and its thickness is in the range of 40 to $100 \mathrm{~m}$. The basaltic sheet (vb) flows cap the Oligocene sediments in some parts (Moustafa and Abd-Allah (1991). They are scattered in some localities as shown in Wadi El-Halazouni area and its vicinities.

- Miocene rocks; is represented by the Upper Miocene non-marine deposits of Hagul Formation (Tmh), which consists of fluviatile sand and gravel.

- Pliocene sediments: is represented by Kom El-Shelul Formation (Tplk), which consists of marine section of yellowish brown, gritty calcareous sandstone (2-5 m) (UNDP et al., 2008). Overlying Kom El-Shelul formation, undifferentiated Pliocene deposits (Tpl) are 
existed at the North of El-Faiyum, which is possibly younger (CONOCO, 1987).

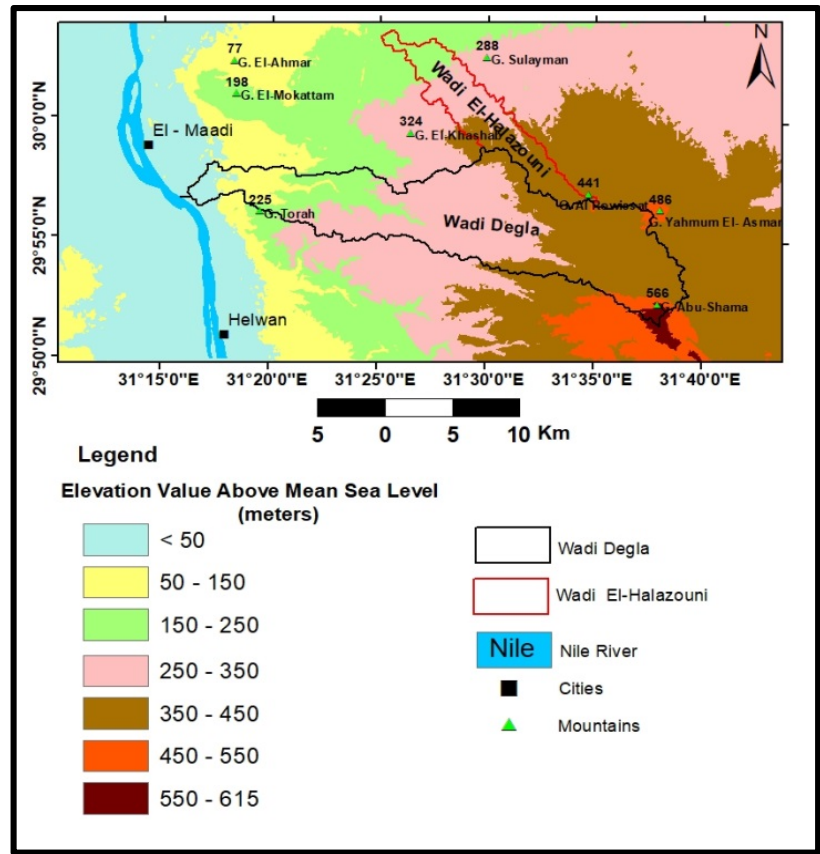

Fig. (2). Digital Elevations Model (DEM) map of the study area.

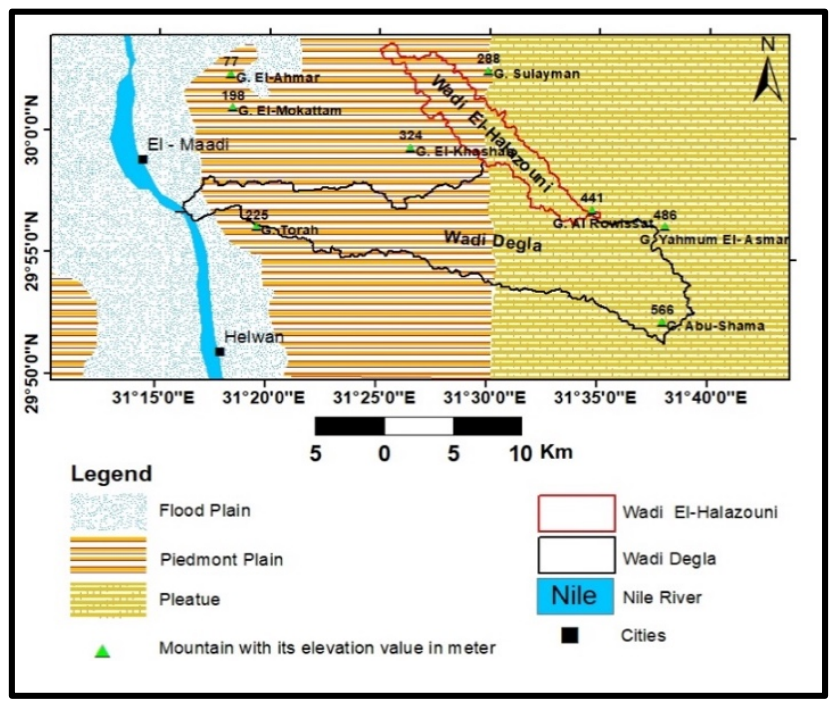

Fig. (3). Geomorphological map of the study area.

Egyptian J. Desert Res., 70, No. 1, 25-57 (2020) 


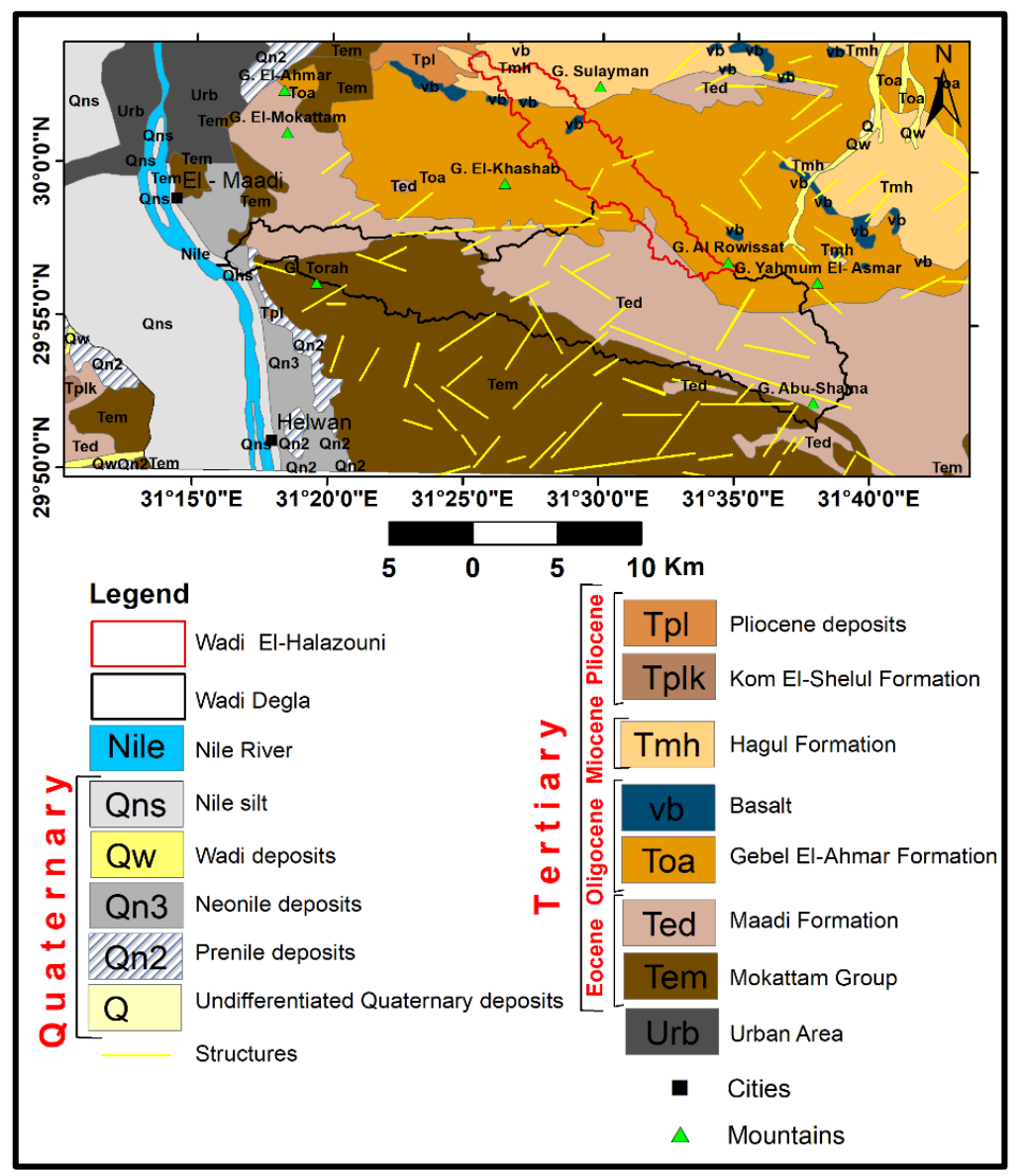

Fig. (4). Geological map of the study area.

\section{Quaternary deposits}

It forms the floor of the wadis, which drains to the Nile. It covers all the area around the Nile as well as the cultivated lands. It is made up of silt and clay with sand interbeds (UNDP et al., 2008).

From the structure point of view, the geologic map was used to determine the existed faults and lineaments to construct the distribution of their frequency and lengths through a rose diagram (Fig. 5). This rose diagram revealed the presence of three main sets of normal faults-oriented NE-SW, NW-SE and NNE-SSW are delineated in the study area. The main trend of fault NE-SW is parallel to the main trends of the Gulf of Aqaba, while the fault NW-SE is parallel to the Gulf of Suez. Wadi El-Halazouni has the same direction of the structure NW-SE.

Egyptian J. Desert Res., 70, No. 1, 25-57 (2020) 


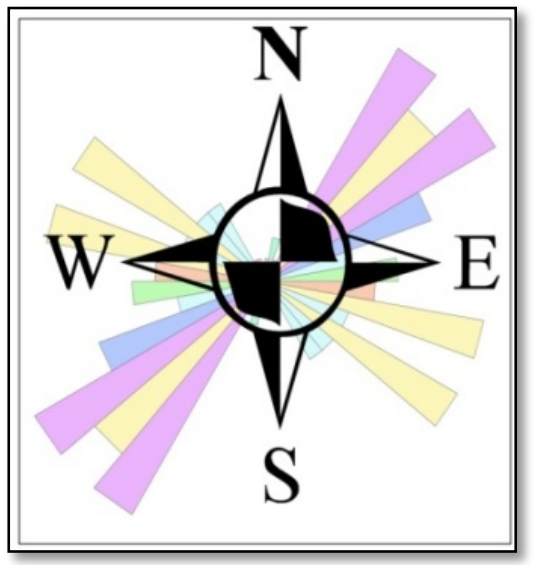

Fig. (5). Rose Diagram of lineaments in the study area.

\section{MATERIALS AND METHODS}

To achieve the objectives of this study, the following data and methods were used:

- Climatic data of the Egyptian Metrological Authority (EMA, 1949-

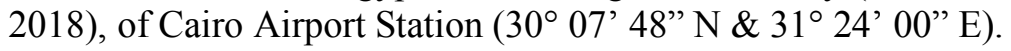

- The rainfall data of the storm occurred on 24-25 April 2018 was collected from the website for satellite data (GSMAP).

- The topographic maps with scales 1:25,000 (Military Survey, 20082009) and 1:50,000 (EGSA, 1991-1997).

- The geologic maps with scale 1:50,0000 (CONOCO, 1987).

- Two satellite images were used to classify the wadis and create the land use thematic maps. The area under consideration is a part of a scene path/row: 176/39, of the Landsat-5 Thematic Mapper TM from the United States geological Survey (USGS) Earth Explorer, Landsat_Scene_ID: "LT51760391984280FUI00" (date of image acquisition, 6 October 1984) and Sentinel-2A from the European Environment Agency Copernicus Access Hub. Entity ID: "L1C_T36RUU_A015033_20180509T083704" (date of image acquisition: 9 May 2018).

- ARC/Map software version 10.2.2 Copyright (1999-2014) and Erdas/Imagine 9.2 (2014) for maps analysis (Rectification, Sub-set and Mosaic)

- HEC-HMS software version 4 (2010) for storm analysis and rainfall-runoff calculation.

- Two field trips were carried out to investigate the Protectorate area in Wadi Degla and to verify the image classification of the land use in both wadis. 


\section{RESULTS AND DISCUSSION}

\section{Morphometric Analysis of Basins}

Morphometric analysis of the studied basins is essentially based on the geomorphological features and morphometric parameters. These analyses are prepared by tracing the drainage network using digital elevation model (DEM) with $30 \mathrm{~m}$ resolution and topographic maps (scale 1:25,000). Depending on Strahler method (Strahler, 1957), the streams are ordered, and the different parameters are measured and calculated according to Horton (1945). As a result, Wadi Degla is a sixth order stream type, while Wadi ElHalazouni is fourth order type (Fig. 6). The results are tabulated in tables (1 and 2) from which, the following parameters can be discussed in some details:

\subsection{Texture ratio}

The texture ratio $(\mathrm{Tr})$ is computed as the ratio between the sum of stream number and the perimeter of the basin. Morisawa (1957) classified the texture ratio to; less than 8 streams $/ \mathrm{km}$ (coarse texture), $8-20$ streams $/ \mathrm{km}$ (medium texture), 20-200 streams/km (soft texture) and more than 200 streams $/ \mathrm{km}$ (very soft texture). The texture ratio of Wadi Degla and Wadi El-Halazouni belongs to category one (coarse texture). According to Schumm (1965), the lower value of texture ratio (coarse texture) indicates that it has a good chance for groundwater recharge.

\subsection{Sinuosity ratio}

The valley length $\left(\mathrm{L}_{\mathrm{v}}\right)$ is the total length of the main trunk, while the basin length $\left(\mathrm{L}_{b}\right)$ is the shortest distance between the mouth and source of stream (Mueller, 1968). The sinuosity ratio is the ratio between the valley length and the basin length. As such, it represents the degree of meandering. The straight valley is more effective in flooding than the meandering one. The sinuosity ratio (Si) of the studied drainage basins of Wadi Degla and Wadi El-Halazouni are 1.174 and 1.153, respectively. These values indicate less meandering nature, which increase effectiveness of flooding.

\subsection{Form factor ratio}

It is defined as a numerical index that shows the shape of the basin and its value ranges from 0.1 to 0.8 (Horton, 1932). The values of the study basins are 0.135 and 0.115 for Wadi Degla and Wadi El-Halazouni, respectively. These low values indicate that the basins have elongated shape and lower peak runoff of longer duration is expected.

Egyptian J. Desert Res., 70, No. 1, 25-57 (2020) 


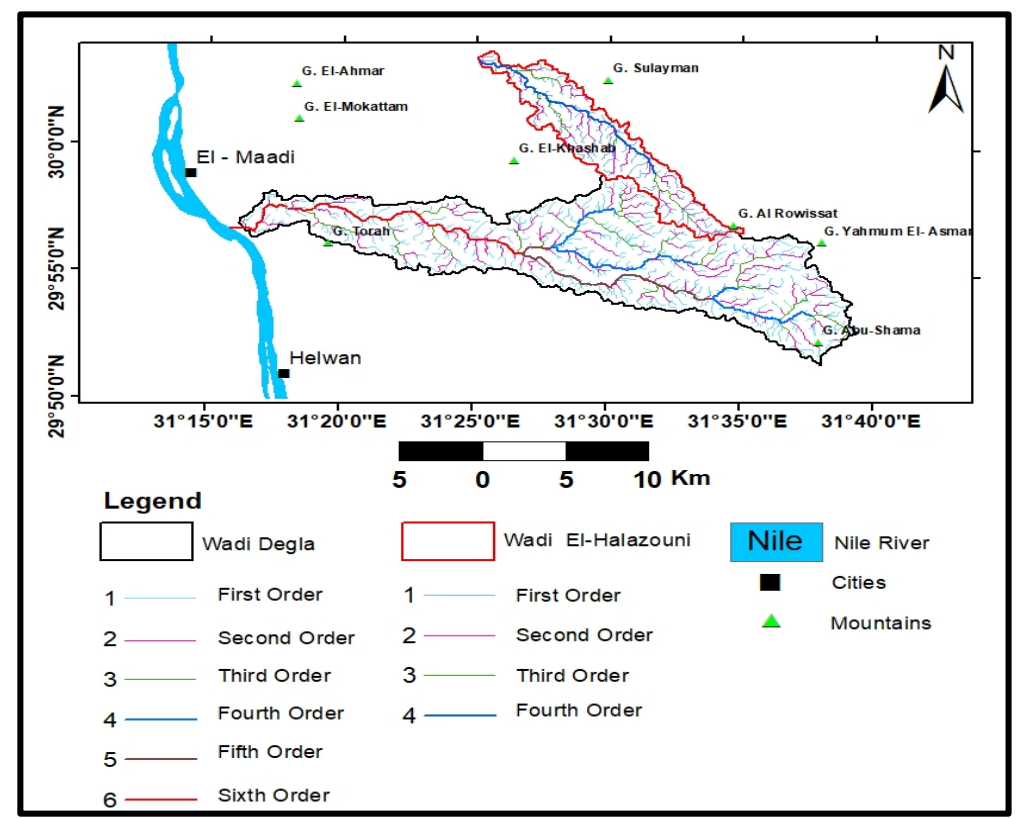

Fig. (6). Stream orders map of Wadi Degla and Wadi El-Halazouni.

Table (1). Basic data of the studied wadis.

\begin{tabular}{lccc}
\hline Name & Wadi & Wadi El-Halazouni \\
\hline \multicolumn{2}{l}{ Area $(\mathrm{A})\left(\mathrm{km}^{2}\right)$} & 194.950 & 47.920 \\
\hline \multicolumn{2}{l}{ Perimeter $(\mathrm{P})(\mathrm{km})$} & 111.064 & 57.938 \\
\hline \multicolumn{2}{l}{ Basin Width $(\mathrm{w})(\mathrm{km})$} & 5.130 & 2.350 \\
\hline \multicolumn{2}{l}{ Order of trunk channel } & $6^{\text {th }}$ & $4^{\text {th }}$ \\
\hline \multicolumn{2}{l}{ Direction of main trunk } & East-West & Southeast- Northwest \\
\hline First & Stream no. & 603 & 152 \\
order & Length $(\mathrm{m})$ & 238500 & 63804 \\
\hline Second & Stream no. & 132 & 32 \\
order & Length $(\mathrm{m})$ & 127960 & 29099 \\
\hline Third & Stream no. & 22 & 6 \\
order & Length $(\mathrm{m})$ & 44300 & 13878 \\
\hline Fourth & Stream no. & 4 & 1 \\
order & Length $(\mathrm{m})$ & 25800 & 15466 \\
\hline $\begin{array}{l}\text { Fifth } \\
\text { order }\end{array}$ & Stream no. & 2 & \\
\hline $\begin{array}{l}\text { Sixth } \\
\text { order }\end{array}$ & Length $(\mathrm{m})$ & 16100 & \\
\hline
\end{tabular}

Egyptian J. Desert Res., 70, No. 1, 25-57 (2020) 
Table (2). Morphometric parameters of the studied wadis.

\begin{tabular}{|c|c|c|c|}
\hline Name & Unit & Wadi & Wadi El- \\
\hline Parameters & UnIt & Degla & Halazouni \\
\hline Sum of stream numbers $\left(\sum \mathrm{N}_{\mathrm{u}}\right)$ & & 764 & 191 \\
\hline Sum of stream lengths $\left(\sum \mathrm{L}_{\mathrm{u}}\right)$ & $\mathrm{km}$ & 474.96 & 122.25 \\
\hline Valley Length $\left(\mathrm{L}_{\mathrm{V}}\right)$ & $\mathrm{km}$ & 44.60 & 23.52 \\
\hline Basin Length $\left(\mathrm{L}_{\mathrm{b}}\right)$ & $\mathrm{km}$ & 38.00 & 20.40 \\
\hline Texture Ratio $(\mathrm{Tr}=\mathrm{Nu} / \mathrm{P})$ & $\mathrm{km}^{-1}$ & 6.879 & 3.297 \\
\hline Sinuosity Ratio $\left(\mathrm{S}_{\mathrm{i}}=\mathrm{L}_{\mathrm{v}} / \mathrm{L}_{\mathrm{b}}\right)$ & & 1.174 & 1.153 \\
\hline Form Factor Ratio $\left(\mathrm{FFR}=\left(\mathrm{A} / \mathrm{L}_{\mathrm{b}}{ }^{2}\right)\right.$ & & 0.135 & 0.115 \\
\hline Compactness Ratio $(\mathrm{SH}=\mathrm{P} / 2(\sqrt{ } \pi \mathrm{A})$ & & 2.243 & 2.361 \\
\hline Shape Index $\left(\mathrm{Ish}=1.27 \mathrm{~A} / \mathrm{L}_{\mathrm{b}}^{2}\right)$ & & 0.172 & 0.146 \\
\hline Circularity Ratio $\left(\mathrm{Rc}=4 \prod \mathrm{A} / \mathrm{P}^{2}\right)$ & & 0.200 & 0.180 \\
\hline Elongation Ratio $\left(\mathrm{Re}=(2 \sqrt{\mathrm{A}} / \pi) / \mathrm{L}_{\mathrm{b}}\right.$ & & 0.415 & 0.383 \\
\hline Bifurcation Ratio $\mathrm{Rb}=\left(\sum \mathrm{N}_{\mathrm{u}} / \sum \mathrm{N}_{\mathrm{u}+1}\right)$ & & 4.010 & 5.360 \\
\hline $\begin{array}{l}\text { Weighted Mean Bifurcation Ratio } \\
\mathrm{WMRb}=\left(\sum \mathrm{Rb}_{\mathrm{u}} / \mathrm{Rb}_{\mathrm{u}+1}\right)\left(\mathrm{N}_{\mathrm{u}}+\mathrm{N}_{\mathrm{u}+1}\right) /\left(\sum \mathrm{N}_{\mathrm{u}+1}\right)\end{array}$ & & 4.800 & 4.885 \\
\hline Drainage Density $\left(D=\left(\sum \mathrm{L}_{\mathrm{u}} / \mathrm{A}\right)\right.$ & $\mathrm{km}^{-1}$ & 2.436 & 2.551 \\
\hline Stream Frequency $\left(\mathrm{F}=\left(\sum \mathrm{N}_{\mathrm{u}} / \mathrm{A}\right)\right.$ & $\mathrm{km}^{-2}$ & 3.919 & 3.986 \\
\hline Upstream Elevation & $\mathrm{m}$ & 561.00 & 445.00 \\
\hline Downstream Elevation & $\mathrm{m}$ & 9.00 & 173.00 \\
\hline Relief $(\mathrm{R})$ & $\mathrm{m}$ & 552.00 & 272.00 \\
\hline Relief Ratio $\left(\mathrm{R}_{\mathrm{f}}=\mathrm{R} / \mathrm{L}_{\mathrm{b}}\right)$ & $\mathrm{m} / \mathrm{m}$ & 0.015 & 0.013 \\
\hline Ruggedness No. $(\mathrm{Rn}=\mathrm{R} * \mathrm{D})$ & & 1.345 & 0.694 \\
\hline Length of overland Flow $(\mathrm{Lo}=1 / 2 \mathrm{D})$ & $\mathrm{km}$ & 0.205 & 0.196 \\
\hline $\begin{array}{l}\text { Hypsometric integral } \\
\mathrm{HI}=\left(\frac{\text { Mean Elevation }- \text { Minimum Elevation }}{\text { Maximum Elevation-Minimum Elevation }}\right)\end{array}$ & & 0.353 & 0.176 \\
\hline
\end{tabular}

\subsection{Compactness ratio}

It is the ratio between the perimeter of the basin and the circumference of a circle of equal area as the basin (Horton, 1945). The calculated compactness ratios for the drainage basins are 2.243 for Wadi Degla and 2.361 for Wadi El-Halazouni. This means that the basins have elongated shape.

\subsection{Shape index}

The basin shape index (Ish) described the relation between the area and the length of the basin. It is defined as the relation between the basin area and the square of the basin length (Hagget, 1956). The calculated values

Egyptian J. Desert Res., 70, No. 1, 25-57 (2020) 
are 0.172 for Wadi Degla and 0.146 for Wadi El-Halazouni. These values indicate that the basin length is long, which indicate a good chance for groundwater recharge.

\subsection{Circularity ratio}

The circularity ratio $(\mathrm{Rc})$ is defined as the ratio between basin area and the area of a circle having the same perimeter of the basin. The circularity ratio approaches one if the basin shape is circle, and it tends to zero if the basin is rectangular (Miller, 1953). The time of concentration of flow is less in circular basins than in elongated one. In the study area, Wadi Degla and Wadi El-Halazouni have low values 0.20 and 0.180 , respectively. This means that these basins are characterized by elongated shape and low runoff volume.

\subsection{Elongation ratio}

Elongation ratio was defined by Schumm (1956) as the ratio between the diameter of circle with the same area basin and the basin length. The calculated values are 0.415 and 0.383 for Wadi Degla and Wadi ElHalazouni, respectively, which indicate that these basins are near elongation and far from circulation.

\subsection{Bifurcation ratio and weighted mean bifurcation ratio}

The bifurcation ratio is defined as the ratio between the number of streams of a given order $\left(\mathrm{N}_{\mathrm{u}}\right)$ to the number of streams to the next order $\left(\mathrm{N}_{\mathrm{u}+1}\right)$ (Horton, 1945). Smart (1972) declared that the bifurcation characteristically ranges between 3 and 5 for watersheds in which the geologic structures do not distort the drainage pattern. Drainage basins with small Bifurcation Ratio values are potentially subjected to flash floods, whereas those of large values commonly have reduced flood capability (McCullagh, 1978). The calculated values for Wadi Degla and Wadi ElHalazouni are 4.01 and 5.36, respectively. To arrive at a more representative bifurcation number, Strahler (1952) proposed a weighted mean bifurcation ratio obtained by multiplying the bifurcation ratio for each successive pair of orders by the total numbers of streams involved in the ratio and taking the mean of the sum of these values (Table 2). The values of the weighted mean bifurcation ratio calculated, are very close to each other (4.80 for Wadi Degla and 4.885 for Wadi El-Halazouni).

\subsection{Drainage density}

Drainage density (D) is defined as the ratio between total lengths of stream segments of all stream orders within the given basin to the total area (Horton, 1945). Drainage density reflects the effectiveness of the overland flow. Regions of high drainage density are associated with larger flood flows and low proportion of groundwater contribution (Osrborn, 1970). In the study area, the drainage density values are $2.43 \mathrm{~km}^{-1}$ for Wadi Degla and $2.55 \mathrm{~km}^{-1}$ for Wadi El-Halazouni. These low values indicate that the most rainfall quantity infiltrates to recharge the groundwater. 


\subsection{Stream frequency}

The stream frequency $(\mathrm{F})$ is defined as the number of segments of all orders per unit area (Horton, 1945). It reflects the fact that more streams per unit area enable runoff to proceed faster because the stream network can carry a large amount of water. The high values of stream frequency in the study area $\left(3.919 \mathrm{~km}^{-2}\right.$ for Wadi Degla and $3.986 \mathrm{~km}^{-2}$ for Wadi El Halzouni) show a high possibility of runoff water collection.

\subsection{Relief ratio}

Relief ratio (R) is the average steepness of the drainage basin. This value provides a rapid measure that reflects the factors controlling surface runoff (Chorely, 1969). With increasing relief, time of concentration of runoff will decrease, increasing potential of flooding. The relief ratio values are $0.015 \mathrm{~m} / \mathrm{m}$ for Wadi Degla and $0.013 \mathrm{~m} / \mathrm{m}$ for Wadi El-Halazouni.

\subsection{Ruggedness number}

The ruggedness number $(\mathrm{Rn})$ is the product of relief and drainage density (Melton, 1957). The great value of ruggedness number reflects greater runoff. It varies between 1.345 (Wadi Degla) and 0.694 (Wadi ElHalazouni). This means that Wadi Degla generates runoff more than Wadi El-Halazouni.

\subsection{Length of overland flow}

It is defined as the distance that water flows over the ground surface before it becomes concentrated in drainage channel. It is expressed by the reciprocal of twice the drainage density. The shorter the length of overland flow, the quicker the surface runoff will enter the stream (Horton, 1945). It ranges between $0.205 \mathrm{~km}$ (Wadi Degla) and $0.196 \mathrm{~km}$ (Wadi El-Halazouni).

\subsection{Hypsometric integral}

The hypsometric integral (HI) is computed and described by Strahler (1952). The calculated (HI) values of Wadi Degla and Wadi El-Halazouni are 0.353 and 0.176, respectively. Singh and Sharma (2008) presented an HI-based classification for the main landscape development stages. According to his classification, basins with (HI) values above 0.6 were classified as young, whereas catchments with (HI) values below 0.3 were classified as old. Mature stage catchments have (HI) values greater than 0.3 and lower than 0.6. According to this classification, Wadi Degla is classified as mature stage basin, while Wadi El-Halazouni is old stage basin.

Based on the above-mentioned parameters, it can be concluded that, Wadi Degla and Wadi El-Halazouni have almost the same characteristics. The Wadis are elongated in shape and have lower peak runoff of longer duration over its area.

\section{Probability and Return Period Analysis}

The most common means used in hydrology to indicate the probability of an event is to assign its return period, which is a statistical period in which an event of the given magnitude might happen. The 
relationship between the probability of exceedence $\mathrm{G}(\mathrm{x})$ and return period $\mathrm{T}$ is given by the following formula (Ponce, 1989):

$$
\mathrm{G}(\mathrm{x})=1 / \mathrm{T} \text {. }
$$

The most universally applied formula for calculating the return period (T) for a particular flood peak is that of Weibull method (Brook, 1986):

Where:

$$
\mathrm{T}=(\mathrm{N}+1) / \mathrm{m}
$$

$\mathrm{N}$ : is the number of events in the series, the highest of every year.

$\mathrm{m}$ : is the rank (from largest to smallest) of each event in the series

Using the rainfall records of 70 years from 1949 to 2018 for Station of Cairo Airport, the return period for the maximum monthly rainfall and the probability of exceedence are tabulated (Table 3 ).

The relation between the return period and the maximum monthly rainfall for this station is plotted using a semi log paper (Fig. 7). A line can be fitted to the points to get the following equation:

$$
\mathrm{Y}=9.369 \ln (\mathrm{x})+3.635 \text {. }
$$

Where: $\mathrm{Y}=$ Maximum monthly rainfall $(\mathrm{mm}), \mathrm{x}=\mathrm{T}=$ Return period (years)

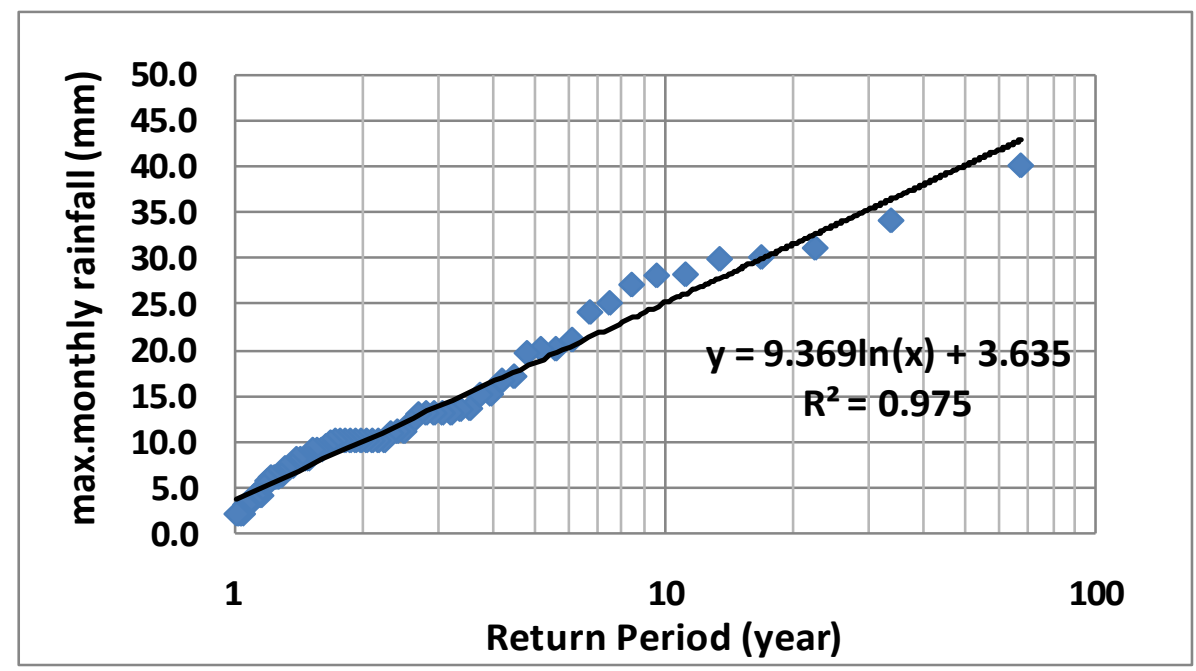

Fig. (7). Relationship between Return period (years) and maximum monthly rainfall for Cairo Airport Station (1949 - 2018). 
Table (3). Return period and probability of exceedence for maximum monthly rainfall for Cairo Airport Station (1949 - 2018).

\begin{tabular}{|c|c|c|c|c|c|c|}
\hline \multirow[b]{2}{*}{ Year } & \multirow[b]{2}{*}{$\begin{array}{l}\text { Max. monthly } \\
\text { rainfall (mm) }\end{array}$} & \multicolumn{2}{|c|}{ Rainfall (descending) } & \multirow[b]{2}{*}{ Rank } & \multirow{2}{*}{$\begin{array}{l}\text { Return } \\
\text { period (T) } \\
\text { (year) }\end{array}$} & \multirow{2}{*}{$\begin{array}{c}\text { Probability } \\
\text { of } \\
\text { exceedance } \\
(G(x))(\%)\end{array}$} \\
\hline & & Year & $\begin{array}{l}\text { Max. rainfall } \\
\quad(\mathrm{mm})\end{array}$ & & & \\
\hline 1949 & 31.00 & 2018 & 40.00 & 1 & 67 & 1.49 \\
\hline 1950 & 10.00 & 2017 & 34.00 & 2 & 34 & 2.99 \\
\hline 1951 & 7.00 & 1949 & 31.00 & 3 & 22 & 4.48 \\
\hline 1952 & 20.00 & 1991 & 30.00 & 4 & 17 & 5.97 \\
\hline 1953 & 10.00 & 2010 & 29.80 & 5 & 13 & 7.46 \\
\hline 1954 & 10.00 & 2002 & 28.12 & 6 & 11 & 8.96 \\
\hline 1955 & 10.00 & 1974 & 28.00 & 7 & 10 & 10.45 \\
\hline 1956 & 20.00 & 1981 & 27.00 & 8 & 8 & 11.94 \\
\hline 1957 & 5.00 & 1987 & 25.00 & 9 & 7 & 13.43 \\
\hline 1958 & 2.00 & 1971 & 24.00 & 10 & 7 & 14.93 \\
\hline 1959 & 10.00 & 1972 & 21.00 & 11 & 6 & 16.42 \\
\hline 1960 & 10.00 & 1956 & 20.00 & 12 & 6 & 17.91 \\
\hline 1961 & 10.00 & 1952 & 20.00 & 13 & 5 & 19.40 \\
\hline 1966 & 2.00 & 2004 & 19.55 & 14 & 5 & 20.90 \\
\hline 1967 & 4.00 & 1988 & 17.00 & 15 & 4 & 22.39 \\
\hline 1968 & 6.00 & 2000 & 16.55 & 16 & 4 & 23.88 \\
\hline 1969 & 15.00 & 2011 & 15.07 & 17 & 4 & 25.37 \\
\hline 1970 & 10.00 & 1969 & 15.00 & 18 & 4 & 26.87 \\
\hline 1971 & 24.00 & 1979 & 13.50 & 19 & 4 & 28.36 \\
\hline 1972 & 21.00 & 1994 & 13.40 & 20 & 3 & 29.85 \\
\hline 1973 & 6.00 & 1992 & 13.00 & 21 & 3 & 31.34 \\
\hline 1974 & 28.00 & 1990 & 13.00 & 22 & 3 & 32.84 \\
\hline 1975 & 9.00 & 1984 & 13.00 & 23 & 3 & 34.33 \\
\hline 1976 & 3.00 & 1978 & 13.00 & 24 & 3 & 35.82 \\
\hline 1977 & 8.00 & 2008 & 12.88 & 25 & 3 & 37.31 \\
\hline 1978 & 13.00 & 1986 & 12.00 & 26 & 3 & 38.81 \\
\hline 1979 & 13.50 & 1985 & 11.00 & 27 & 2 & 40.30 \\
\hline 1980 & 9.00 & 1982 & 11.00 & 28 & 2 & 41.79 \\
\hline 1981 & 27.00 & 2006 & 10.80 & 29 & 2 & 43.28 \\
\hline 1982 & 11.00 & 2016 & 10.00 & 30 & 2 & 44.78 \\
\hline 1983 & 10.00 & 1983 & 10.00 & 31 & 2 & 46.27 \\
\hline 1984 & 13.00 & 1970 & 10.00 & 32 & 2 & 47.76 \\
\hline 1985 & 11.00 & 1961 & 10.00 & 33 & 2 & 49.25 \\
\hline 1986 & 12.00 & 1960 & 10.00 & 34 & 2 & 50.75 \\
\hline
\end{tabular}

Egyptian J. Desert Res., 70, No. 1, 25-57 (2020) 
Table (3) Cont.

\begin{tabular}{|c|c|c|c|c|c|c|}
\hline \multirow[b]{2}{*}{ Year } & \multirow{2}{*}{$\begin{array}{c}\text { Max. } \\
\text { monthly } \\
\text { rainfall }(\mathbf{m m})\end{array}$} & \multicolumn{2}{|c|}{ Rainfall (descending) } & \multirow[b]{2}{*}{ Rank } & \multirow{2}{*}{$\begin{array}{c}\text { Return } \\
\text { period (T) } \\
\quad(\text { year) }\end{array}$} & \multirow{2}{*}{$\begin{array}{c}\begin{array}{c}\text { Probability } \\
\text { of }\end{array} \\
\text { exceedance } \\
(\mathbf{G}(\mathbf{x}))(\%)\end{array}$} \\
\hline & & Year & $\begin{array}{l}\text { Max. rainfall } \\
\quad(\mathrm{mm})\end{array}$ & & & \\
\hline 1987 & 25.00 & 1959 & 10.00 & 35 & 2 & 52.24 \\
\hline 1988 & 17.00 & 1955 & 10.00 & 36 & 2 & 53.73 \\
\hline 1989 & 8.00 & 1954 & 10.00 & 37 & 2 & 55.22 \\
\hline 1990 & 13.00 & 1953 & 10.00 & 38 & 2 & 56.72 \\
\hline 1991 & 30.00 & 1950 & 10.00 & 39 & 2 & 58.21 \\
\hline 1992 & 13.00 & 2007 & 9.80 & 40 & 2 & 59.70 \\
\hline 1993 & 4.00 & 2003 & 9.40 & 41 & 2 & 61.19 \\
\hline 1994 & 13.40 & 2013 & 9.00 & 42 & 2 & 62.69 \\
\hline 1995 & 6.00 & 1980 & 9.00 & 43 & 2 & 64.18 \\
\hline 1996 & 7.00 & 1975 & 9.00 & 44 & 2 & 65.67 \\
\hline 1997 & 8.00 & 2014 & 8.00 & 45 & 1 & 67.16 \\
\hline 1998 & 2.00 & 1997 & 8.00 & 46 & 1 & 68.66 \\
\hline 1999 & 4.00 & 1989 & 8.00 & 47 & 1 & 70.15 \\
\hline 2000 & 16.55 & 1977 & 8.00 & 48 & 1 & 71.64 \\
\hline 2001 & 3.51 & 2005 & 7.20 & 49 & 1 & 73.13 \\
\hline 2002 & 28.12 & 1996 & 7.00 & 50 & 1 & 74.63 \\
\hline 2003 & 9.40 & 1951 & 7.00 & 51 & 1 & 76.12 \\
\hline 2004 & 19.55 & 2012 & 6.20 & 52 & 1 & 77.61 \\
\hline 2005 & 7.20 & 1995 & 6.00 & 53 & 1 & 79.10 \\
\hline 2006 & 10.80 & 1973 & 6.00 & 54 & 1 & 80.60 \\
\hline 2007 & 9.80 & 1968 & 6.00 & 55 & 1 & 82.09 \\
\hline 2008 & 12.88 & 2009 & 5.60 & 56 & 1 & 83.58 \\
\hline 2009 & 5.60 & 1957 & 5.00 & 57 & 1 & 85.07 \\
\hline 2010 & 29.80 & 1999 & 4.00 & 58 & 1 & 86.57 \\
\hline 2011 & 15.07 & 1993 & 4.00 & 59 & 1 & 88.06 \\
\hline 2012 & 6.20 & 1967 & 4.00 & 60 & 1 & 89.55 \\
\hline 2013 & 9.00 & 2001 & 3.51 & 61 & 1 & 91.04 \\
\hline 2014 & 8.00 & 2015 & 3.00 & 62 & 1 & 92.54 \\
\hline 2015 & 3.00 & 1976 & 3.00 & 63 & 1 & 94.03 \\
\hline 2016 & 10.00 & 1998 & 2.00 & 64 & 1 & 95.52 \\
\hline 2017 & 34.00 & 1966 & 2.00 & 65 & 1 & 97.01 \\
\hline 2018 & 40.00 & 1958 & 2.00 & 66 & 1 & 98.51 \\
\hline
\end{tabular}

From this curve (Fig. 7), the return period of an event of flood can be predicted. When the rainfall increase, the return period becomes longer and vice versa, i.e. a storm of $40.0 \mathrm{~mm}$ is expected to occur each 67 years with a probability of $1.50 \%$, while a rain of $2.0 \mathrm{~mm}$ can occur every year with a probability of $98.5 \%$. 
Table (4) shows the number of occurrences of maximum monthly rainfall in different ranges, from which the following can be concluded:

- The mean maximum monthly rainfall ranges between $10.0 \mathrm{~mm}$ and $15.0 \mathrm{~mm}$, with number of occurrences of 22 years, represents about $33 \%$ of the collected data.

- The second maximum monthly rainfall order is from $5.0 \mathrm{~mm}$ to 10 $\mathrm{mm}$ with 17 years of occurrences representing about $26 \%$ of the collected data

- The maximum monthly rainfall of more than $30.0 \mathrm{~mm}$ occurs only in 3 years $(4.5 \%$ of the collected data).

Table (4). Occurrences of different ranges of maximum monthly rainfall over 66 years.

\begin{tabular}{lccccccc}
\hline $\begin{array}{l}\text { Max. monthly } \\
\text { rainfall (mm) }\end{array}$ & $\begin{array}{c}< \\
\text { (m) }\end{array}$ & $5.0-10.0$ & $10.0-15.0$ & $15.0-20.0$ & $20.0-25.0$ & $25.0-30.0$ & $>30.0$ \\
\hline $\begin{array}{l}\text { No. of occurrence } \\
\text { in 66 years }\end{array}$ & 9 & 17 & 22 & 7 & 3 & 5 & 3 \\
\hline
\end{tabular}

In conclusion, the study area is not subjected to heavy rainfall over the period (66 years). In other words, the storm of April 2018 can be considered as an exceptional event, which may happen only every 67 years. It is noticed that the calculation of the return period is carried out according to the available collected data from 1949-2018, but actually due to the climatic change phenomenon in the last years, it plays an important role in change the normal regime of the monthly rainfall. In other words, the mean monthly rainfall increases in the last four years reaching $56.5 \mathrm{~mm}$ on 12 March, 2020 (GSMAP).

\section{Rainfall-runoff Modeling}

Rainfall-runoff relationships are very important for the catchment management and the protection from the flood hazard. On 24 and 25 April 2018, severe flash flood battered the study area. The heavy rains caused a huge damage in the infrastructures in this area. This heavy storm is selected to be analyzed to calculate the runoff resulting from this storm. The rainfall data is collected from the website for satellite data (GSMAP). The duration of the storm was 7 hours; i.e. the storm began at $6.00 \mathrm{pm}$ in 24 April until 1.00 am in 25 April. Table (5) shows the storm data for Wadi Degla and Wadi El-Halazouni.

Egyptian J. Desert Res., 70, No. 1, 25-57 (2020) 
Table (5). Storm data (April 2018).

\begin{tabular}{ccccc}
\hline Wadi & $\begin{array}{c}\text { Total Storm } \\
(\mathbf{m m})\end{array}$ & $\begin{array}{c}\text { Storm Duration } \\
\text { (hour) }\end{array}$ & $\begin{array}{c}\text { Intensity } \\
(\mathbf{m m} / \mathbf{h o u r})\end{array}$ & $\begin{array}{c}\text { Maximum Rainfall } \\
\text { in hour }(\mathbf{m m})\end{array}$ \\
\hline Wadi Degla & 31.30 & 7 & 4.47 & 10.16 \\
\hline $\begin{array}{c}\text { Wadi } \\
\text { El-Halazouni }\end{array}$ & 33.57 & 7 & 4.80 & 15.40 \\
\hline
\end{tabular}

The Hydrologic Engineering Center-Hydrologic Modeling System (HEC-HMS version 4, 2010) software is applied to analyze and simulate the surface runoff storm. It is applied for Wadis Degla and El-Halazouni. In this study, the loss estimation methods and the lag-time computation methods are used in order to get the suitable parameters for rainfall-runoff relationship. The main elements in this program are:

- Basin model: includes the different elements of water system (area of sub-basin, Lag time, Initial losses, etc.).

- Meteorological model: It concerns with rainfall data including (rainfall value, distribution and duration).

- Control specification: including the time period and time step of the concerned storm (the start and end of the storm and its duration).

\subsection{Model input data}

\subsubsection{Catchment area}

According to the geological and morphometrical characteristics of the studied Wadis, Wadi El-Halazouni is treated as a single basin (47.92 $\mathrm{km}^{2}$ ), while Wadi Degla is subdivided into five sub-basins as shown in table (6). From this table, the data of each sub-basin including catchment area $\left(\mathrm{km}^{2}\right)$, basin length $(\mathrm{km})$, valley length $(\mathrm{km})$, maximum and minimum elevation $(\mathrm{m})$ and average slope $(\mathrm{m} / \mathrm{m})$ are used as input data for the model.

Table (6). Main Data of Sub-basins of Wadi Degla and Wadi El-Halazouni.

\begin{tabular}{cccccccc}
\hline $\begin{array}{c}\text { Name of } \\
\text { Basin }\end{array}$ & Sub-basin & $\begin{array}{c}\text { Sub basin } \\
\left.\text { area } \mathbf{( k m}^{2}\right)\end{array}$ & $\begin{array}{c}\mathbf{L}_{\mathbf{b}} \\
\mathbf{( b a s i n} \\
\text { length) }(\mathbf{k m})\end{array}$ & $\begin{array}{c}\mathbf{L}_{\mathbf{v}} \\
(\mathbf{v a l l e y ~ l e n g t h )} \\
\mathbf{( k m )}\end{array}$ & $\begin{array}{c}\text { Max. } \\
\text { elevation } \\
(\mathbf{m})\end{array}$ & $\begin{array}{c}\text { Min. } \\
\text { elevation } \\
(\mathbf{m})\end{array}$ & $\begin{array}{c}\text { Slope } \\
\mathbf{( m / \mathbf { m } )}\end{array}$ \\
\hline & Sub-Basin1 & 16.61 & 8.792 & 6.92 & 471 & 349 & 0.01763 \\
Wadi & Sub-Basin2 & 31.43 & 11.904 & 8.96 & 570 & 349 & 0.02467 \\
Degla & Sub-Basin3 & 57.81 & 16.06 & 12.86 & 457 & 250 & 0.01609 \\
& Sub-Basin4 & 25.29 & 13.879 & 11.92 & 349 & 244 & 0.00880 \\
& Sub-Basin5 & 63.81 & 27.367 & 17.67 & 314 & 8 & 0.01731 \\
\hline $\begin{array}{c}\text { Wadi } \\
\text { El-Halazouni }\end{array}$ & Basin1 & 47.92 & 20.4 & 23.52 & 445 & 173 & 0.01237 \\
\hline
\end{tabular}

\subsubsection{Rainfall data}

The recorded data of the storm (24-25 April 2018) for each subbasin are used in the HEC-HMS model. The start and end of date and time of 
the storm are entered as input data in the model. The precipitation-time distribution is entered with a time step of one hour.

\subsubsection{Losses calculations}

Rainfall, which doesn't contribute to direct runoff, is a rainfall loss (Ponce, 1989). The initial loss (Ia) is empirically derived from the maximum soil water retention (S), which is related to the soil drainage characteristics (e.g. $\mathrm{CN}$ values). (Ia) accounts normally for losses due to evaporation, plant uptake, and water retained in surface depressions during the rainfall event. (S) accounts for the total amount of water retained in the drainage basin during the rainfall event. Soil Conservation Service (SCS, 1986) method is applied for losses calculations. The equations used for the calculation of initial loss are as follows:

Where:

$$
Q=\frac{(P-0.2 S)^{2}}{(P+0.8 S)} \ldots \ldots . P>0.2 S
$$

$\mathrm{Q}=$ Surface runoff depth $(\mathrm{mm})$

$\mathrm{P}=$ Total rainfall depth $(\mathrm{mm})$

$\mathrm{S}=$ the potential retention parameter or surface storage after runoff begins

$(\mathrm{mm})$ that is a function of an empirical curve number $\mathrm{CN}$ coefficient where:

$$
S=\frac{25400}{C N}-254
$$

$\mathrm{CN}$ is a coefficient that expresses the runoff potential of the area. It is a function of the moisture condition, the land use, the hydrological conditions and the soil type. The method has become widely used because the $\mathrm{CN}$ value is tabulated for a variety of hydrologic conditions, land use types, and soil types. The range of the Curve Number $(\mathrm{CN})$ is obtained from standard tables according to the soil type and cover of each basin. The curve number is always less than 100 . High curve numbers $(>90)$ represent little or no infiltration, while low curve numbers $(<50)$ represent pervious surfaces. A weighted average $\mathrm{CN}$ is calculated according to percentage of the total subcatchment area with its corresponding $\mathrm{CN}$ using the following equation:

$$
\mathrm{CN}=\frac{\sum_{i=1}^{k} A_{i} C N_{i}}{\sum_{i=1}^{k} A_{i}}
$$

Where:

$\mathrm{CN}_{\mathrm{i}}$ corresponds to the appropriate $\mathrm{CN}$ for the part of watershed that has an area $\mathrm{A}_{\mathrm{i}}$. The calculated values of weighted average $\mathrm{CN}$ are shown in table (7 and 8).

\subsubsection{Time of concentration and lag time calculation}

Lag time is an important factor for quantifying the time response of runoff in each basin. It is defined as the time interval from the center of mass of rainfall excess to the center of the peak of runoff hydrograph (Granato, 2010). The lag-time has been estimated as 0.6 Tc (Mockus, 1957), where Tc

Egyptian J. Desert Res., 70, No. 1, 25-57 (2020) 
is the time of concentration and it is calculated according to Kirpich equation as follows:

$$
\mathrm{T}_{\mathrm{c}}=0.0078 \frac{\mathrm{L}^{0.77}}{\mathrm{~S}^{0.385}}
$$

Where:

$\mathrm{T}_{\mathrm{c}}=$ Time of concentration (hours.)

$\mathrm{L}=$ Basin length (length measured along the main stream from outlet to divide) (m)

$\mathrm{S}=$ Slope of the basin $(\mathrm{m} / \mathrm{m})$

The calculated values of time of concentration $\left(\mathrm{T}_{\mathrm{c}}\right)$ and lag time $\left(\mathrm{T}_{\mathrm{L}}\right)$ are shown in table (9).

Table (7). Calculation of $\mathrm{CN}$ in case of rural area for different geological units according to the geologic map.

\begin{tabular}{|c|c|c|c|c|c|}
\hline $\begin{array}{c}\text { Name of } \\
\text { basin }\end{array}$ & Sub-basin & $\begin{array}{l}\text { Geological unit } \\
\text { classification }\end{array}$ & $\begin{array}{c}\text { Area } \\
\left(\mathbf{k m}^{2}\right)\end{array}$ & $\mathbf{C N}$ & $\begin{array}{c}\text { Weighted } \\
\text { CN }\end{array}$ \\
\hline \multirow{11}{*}{$\begin{array}{l}\text { Wadi } \\
\text { Degla }\end{array}$} & \multirow{2}{*}{1} & Toa & 5.54 & 77 & \multirow{2}{*}{82.33} \\
\hline & & Ted & 11.07 & 85 & \\
\hline & \multirow{2}{*}{2} & Ted & 20.95 & 85 & \multirow{2}{*}{83.0} \\
\hline & & Tem & 10.47 & 79 & \\
\hline & \multirow{2}{*}{3} & Toa & 1.58 & 77 & \multirow{2}{*}{84.78} \\
\hline & & Ted & 56.22 & 85 & \\
\hline & \multirow{2}{*}{4} & Ted & 8.43 & 85 & \multirow{2}{*}{81.0} \\
\hline & & Tem & 16.86 & 79 & \\
\hline & \multirow{3}{*}{5} & Ted & 7.47 & 85 & \multirow{3}{*}{79.7} \\
\hline & & Tem & 53.64 & 79 & \\
\hline & & $\mathrm{Q}$ & 2.7 & 79 & \\
\hline \multirow{4}{*}{$\begin{array}{l}\text { Wadi El- } \\
\text { Halazouni }\end{array}$} & \multirow{4}{*}{ - } & Tmh & 6.58 & 77 & \multirow{4}{*}{78.4} \\
\hline & & Toa & 35.2 & 77 & \\
\hline & & Ted & 6.25 & 85 & \\
\hline & & Basalat & 0.5 & 98 & \\
\hline
\end{tabular}

Egyptian J. Desert Res., 70, No. 1, 25-57 (2020) 
Table (8). Calculation of $\mathrm{CN}$ in case of urban area.

\begin{tabular}{|c|c|c|c|c|c|}
\hline $\begin{array}{c}\text { Name of } \\
\text { Basin }\end{array}$ & Sub-basin & $\begin{array}{c}\text { Land use } \\
\text { classification }\end{array}$ & $\begin{array}{c}\text { Area } \\
\left(\mathbf{k m}^{2}\right)\end{array}$ & $\mathbf{C N}$ & $\begin{array}{l}\text { Weighted } \\
\text { CN }\end{array}$ \\
\hline \multirow{20}{*}{$\begin{array}{l}\text { Wadi } \\
\text { Degla }\end{array}$} & \multirow{3}{*}{1} & Desert (Ted) & 15.305 & 85 & \multirow{3}{*}{85.73} \\
\hline & & Buildings & 0.8002 & 92 & \\
\hline & & Asphaltic Roads & 0.5 & 98 & \\
\hline & \multirow{4}{*}{2} & Buildings & 0.525 & 92 & \multirow{4}{*}{85.71} \\
\hline & & Desert (Ted) & 27.68 & 85 & \\
\hline & & Sabkha & 0.9146 & 77 & \\
\hline & & Vegetation & 2.31 & 69 & \\
\hline & \multirow{3}{*}{3} & Desert (Ted) & 46.836 & 85 & \multirow{3}{*}{86.59} \\
\hline & & Buildings & 8.459 & 92 & \\
\hline & & Asphaltic Roads & 2.506 & 98 & \\
\hline & \multirow{5}{*}{4} & Limestone & 6.523 & 85 & \multirow{5}{*}{81.16} \\
\hline & & Desert (Tem) & 17.178 & 79 & \\
\hline & & Buildings & 0.829 & 92 & \\
\hline & & Sabkha & 0.453 & 77 & \\
\hline & & Asphaltic Roads & 0.298 & 98 & \\
\hline & \multirow{5}{*}{5} & Limestone & 8.429 & 85 & \multirow{5}{*}{80.67} \\
\hline & & Desert (Tem) & 49.343 & 79 & \\
\hline & & Buildings & 3.188 & 92 & \\
\hline & & Vegetation & 1.366 & 69 & \\
\hline & & Asphaltic Roads & 1.484 & 98 & \\
\hline \multirow{4}{*}{$\begin{array}{l}\text { Wadi El- } \\
\text { Halazouni }\end{array}$} & \multirow{4}{*}{ - } & Desert (Toa) & 33.52 & 77 & \multirow{4}{*}{80.25} \\
\hline & & Vegetation & 3.862 & 69 & \\
\hline & & Asphaltic Roads & 3.067 & 98 & \\
\hline & & Buildings & 7.576 & 92 & \\
\hline
\end{tabular}

\subsubsection{Routing method}

Routing is the movement of the runoff from the different watersheds outlets throughout the system along the stream, and ultimately to the outlet or sink of the entire watershed system (Chow et al., 1988). The HEC-HMS model routing options include the Muskingum, Modified Plus, Kinematic Wave, and Muskingum - Cunge methods. The routing method used in this work is Muskingum method, which get the best results. The key parameters in Muskingum routing are $\mathrm{K}$ (travel time) and X (weighting of coefficient). The value of $X$ depends on the shape of the wedge storage to be modeled, and ranges from 0.3 with a mean value near 0.25 (Chow et al., 1988). $\mathrm{K}$ is

Egyptian J. Desert Res., 70, No. 1, 25-57 (2020) 


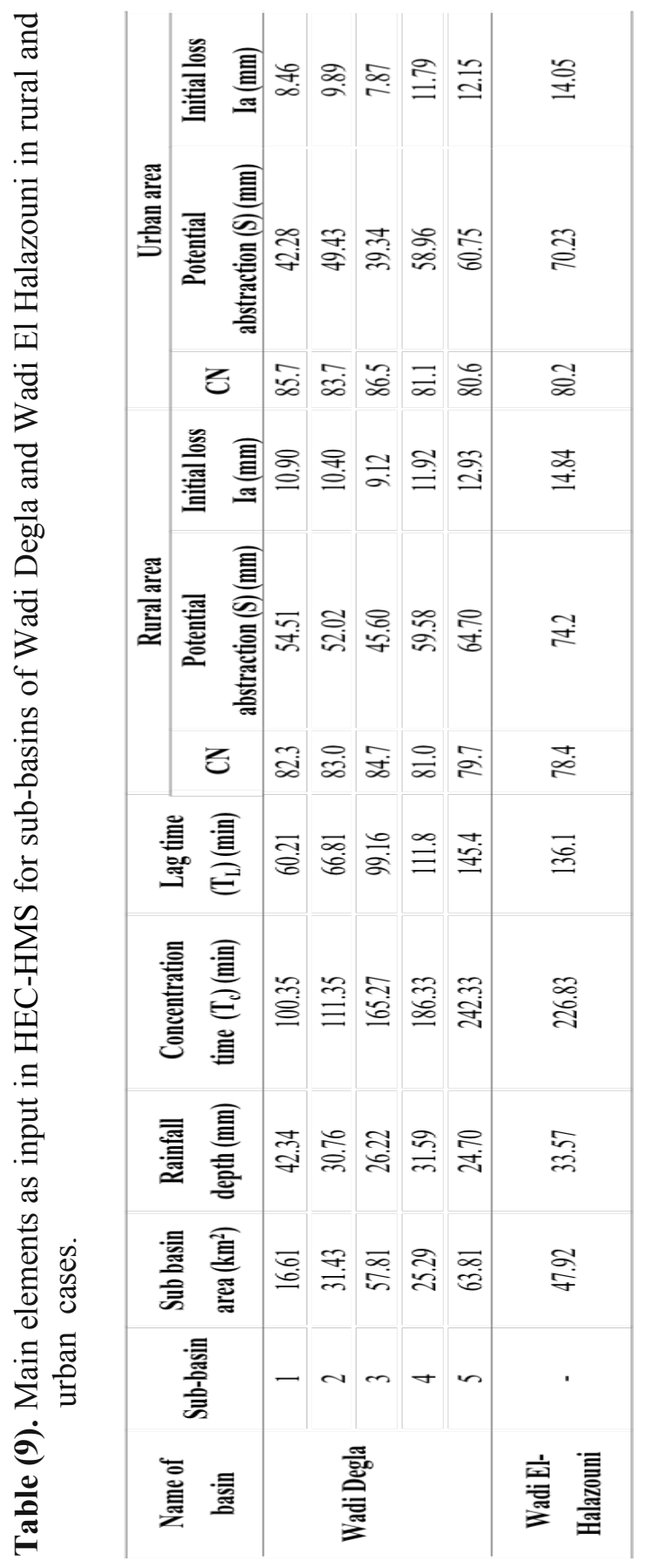

Egyptian J. Desert Res., 70, No. 1, 25-57 (2020) 
the time required for an incremental flood wave to traverse its reach, and it may be estimated as the observed time of travel of peak flow through the reach (Veissman and Lewis, 2003). The following values were used in the program:

$$
\mathrm{X}=0.25 \quad \mathrm{~K}=0.50 \text { hour }
$$

To study the effect of urbanization upon the study area, the rainfall-runoff is calculated in two cases:

- In case of rural area (before any urbanization in the study area i.e. before 1984).

- In case of urban area (after the urbanization in 2018)

In order to achieve this objective, two satellite images covering the study area are used, where one landsat-5 Thematic Mapper (TM) data (path/row: 176/39) acquired on 1984 and Sentinel-2 data (path/row: 176/39) acquired on 2018. To correlate the land use status between the two dates, the false color composite (FCC) bands 4, 2 and 1in red, green and blue colors, respectively for the TM, 1984 and the false color composite (FCC) bands 8,3 and 2 in red, green and blue colors, respectively for the Sentenil2, 2018 are constructed. The detection of changes in land use as an indicator for the urbanization progress is carried out via the classification for the image Sentienl-2, 2018 (Figs. 8, 9 and 10). The curve number is calculated according to the land use of the area as shown in tables ( $7 \& 8)$. Table (9) shows the input data using in the hydrologic model.

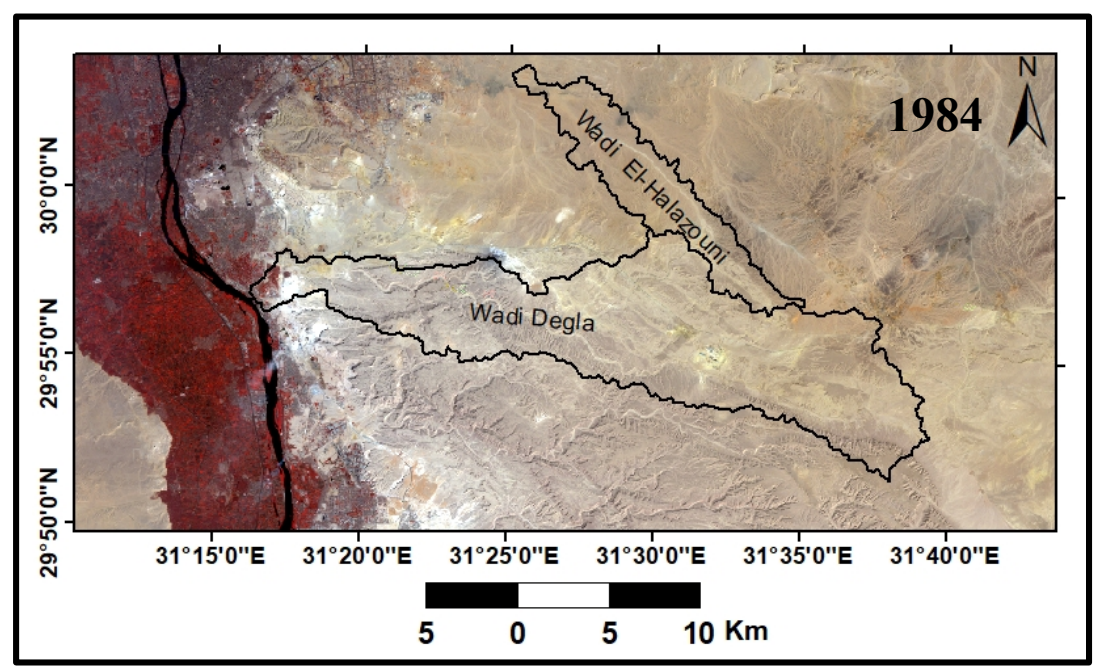

Fig. (8). Landsat-5 TM False Color Composite (FCC) image bands 4 (red), 2 (green) and 1 (blue), 1984. 


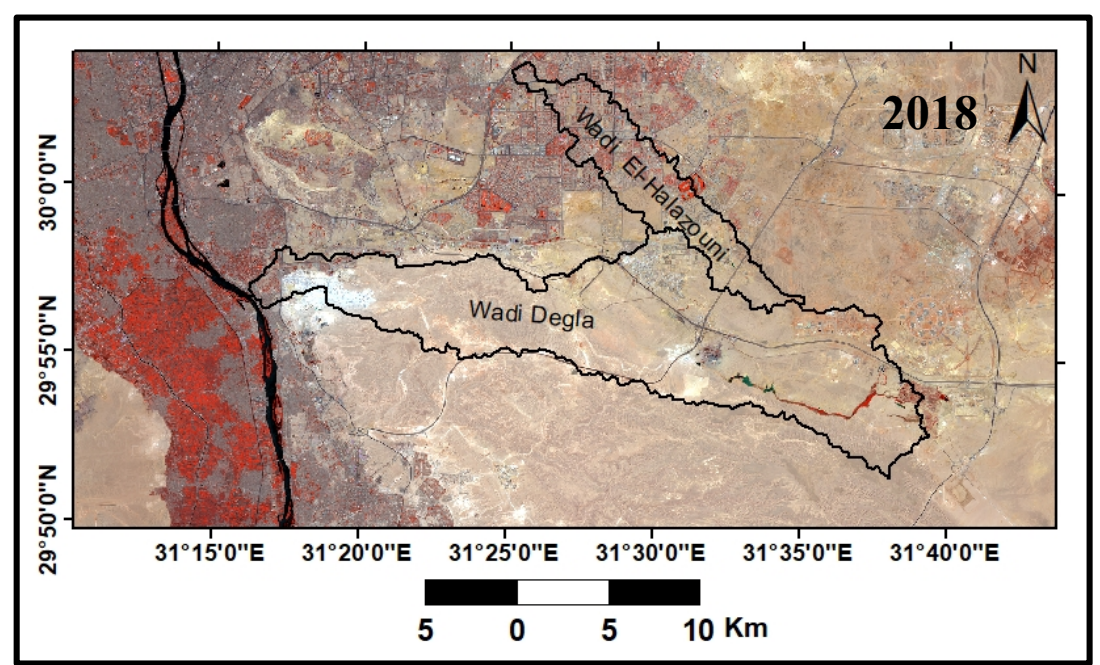

Fig. (9). Sentenil-2 False Color Composite (FCC) image bands 8 (red), 3 (green) and 2 (blue), 2018.

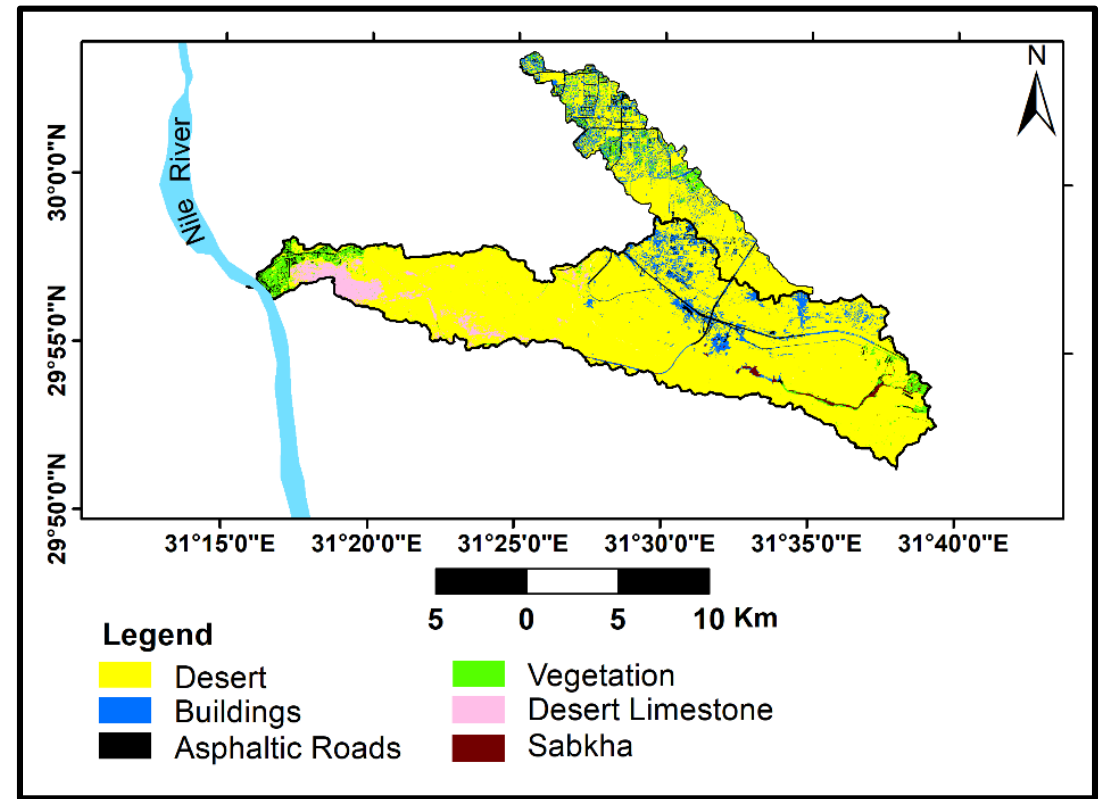

Fig. (10). Thematic map showing the land use for Wadi Degla and Wadi El Halazouni interpreted from Sentenil-2 image, 2018.

Egyptian J. Desert Res., 70, No. 1, 25-57 (2020) 


\subsection{Hydrograph generation}

All the above data are used to generate runoff hydrographs for each sub-basin in Wadi Degla and basin of Wadi El-Halazouni, for the two cases (rural case and urban case). Fig. (11 and 12) are schematic presentation of main sub-basins elements in Wadi Degla and the basin of Wadi ElHalazouni. The main aim of this study is to identify the rainfall-runoff relationship and to estimate the runoff volume, runoff depth and runoff coefficient. The results are tabulated and plotted in table (10) and Fig. $(13,14,15$ and 16).

The runoff depth, which represent the depth of runoff water upon the ground and runoff coefficient, which is the relation between the runoff depth and rainfall depth and represent the amount of rainfall transmitted to runoff are calculated using the following equations (Ponce, 1989):

$$
\begin{aligned}
\text { Runoff Depth } & =\frac{\text { Runoff Volume }}{\text { Drainage Area }} \ldots \ldots \ldots \ldots \\
\text { Runoff Coefficient } & =\frac{\text { Runoff Depth }}{\text { Rainfall Depth }} \ldots \ldots \ldots .
\end{aligned}
$$

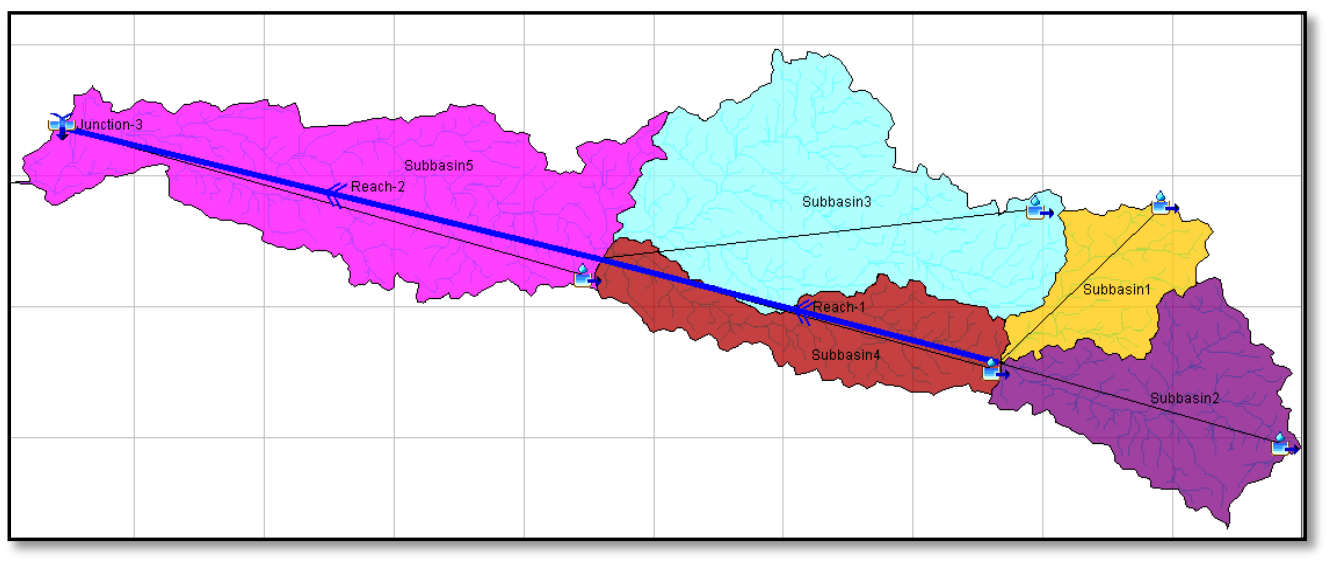

Fig. (11). Schematic presentation of main sub-basins elements of Wadi Degla.

Egyptian J. Desert Res., 70, No. 1, 25-57 (2020) 


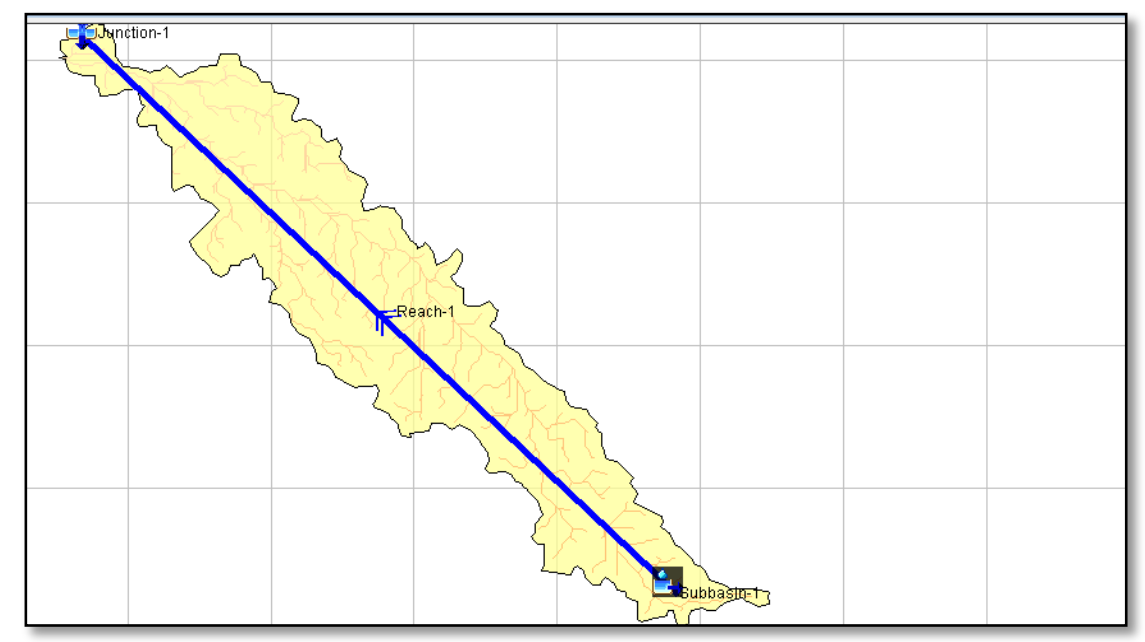

Fig. (12). Schematic presentation of basin (Wadi El-Halazouni).

Table (10). Output parameters of Wadi Degla and Wadi El Halazouni for hydrograph generation using HEC-HM.

\begin{tabular}{|c|c|c|c|c|c|c|c|c|c|}
\hline \multirow[b]{2}{*}{$\begin{array}{c}\text { Name of } \\
\text { Basin }\end{array}$} & \multirow[b]{2}{*}{ Sub-basin } & \multicolumn{4}{|c|}{ Rural case (1984) } & \multicolumn{4}{|c|}{ Urban case (2018) } \\
\hline & & $\begin{array}{c}\text { Peak } \\
\text { discharge } \\
\left(\mathrm{m}^{3} / \mathrm{sec}\right)\end{array}$ & $\begin{array}{c}\text { Runoff } \\
\text { volume } \\
\left(10^{3} \mathbf{m}^{3}\right)\end{array}$ & $\begin{array}{c}\text { Runoff } \\
\text { depth } \\
(\mathbf{m m})\end{array}$ & $\begin{array}{c}\text { Runoff } \\
\text { coeff. } \\
(\%)\end{array}$ & $\begin{array}{c}\text { Peak } \\
\text { discharge } \\
\left(\mathrm{m}^{3} / \mathrm{sec}\right)\end{array}$ & $\begin{array}{l}\text { Runoff } \\
\text { volume } \\
\left(10^{3} \mathrm{~m}^{3}\right)\end{array}$ & $\begin{array}{l}\text { Runoff } \\
\text { depth } \\
(\mathrm{mm})\end{array}$ & $\begin{array}{c}\text { Runoff } \\
\text { coeff. } \\
(\%)\end{array}$ \\
\hline \multirow{8}{*}{$\begin{array}{l}\text { Wadi } \\
\text { Degla }\end{array}$} & Sub-Basin1 & 27.0 & 260.1 & 15.66 & 37.00 & 32.50 & 309.7 & 18.65 & 44.05 \\
\hline & Sub-Basin2 & 33.50 & 296.6 & 9.44 & 30.68 & 35.10 & 309.1 & 9.83 & 31.97 \\
\hline & Reach-1 & 54.80 & 556.7 & - & - & 61.50 & 618.8 & - & - \\
\hline & Sub-Basin3 & 30.20 & 430.6 & 7.45 & 28.41 & 34.60 & 485.7 & 8.40 & 32.05 \\
\hline & Sub-Basin 4 & 8.50 & 133.6 & 5.28 & 16.73 & 8.60 & 134.8 & 5.33 & 16.88 \\
\hline & Reach-2 & 89.30 & 1120.8 & - & - & 99.90 & 1239.2 & - & - \\
\hline & Sub-Basin5 & 17.90 & 313.9 & 4.92 & 19.92 & 19.00 & 331.1 & 5.20 & 21.01 \\
\hline & $\begin{array}{c}\text { Outlet } \\
\text { (Junction-3) }\end{array}$ & 107.20 & 1434.6 & - & - & 118.80 & 1570.4 & - & - \\
\hline \multirow{3}{*}{$\begin{array}{l}\text { Wadi El- } \\
\text { Halazouni }\end{array}$} & Basin1 & 21.70 & 252.5 & 5.27 & 15.70 & 28.20 & 416.8 & 8.70 & 25.91 \\
\hline & Reach1 & 20.80 & 252.3 & - & - & 27.50 & 416.7 & - & - \\
\hline & $\begin{array}{c}\text { Outlet } \\
\text { (Junction1) }\end{array}$ & 20.80 & 252.3 & - & - & 27.50 & 416.7 & - & - \\
\hline
\end{tabular}

Egyptian J. Desert Res., 70, No. 1, 25-57 (2020) 


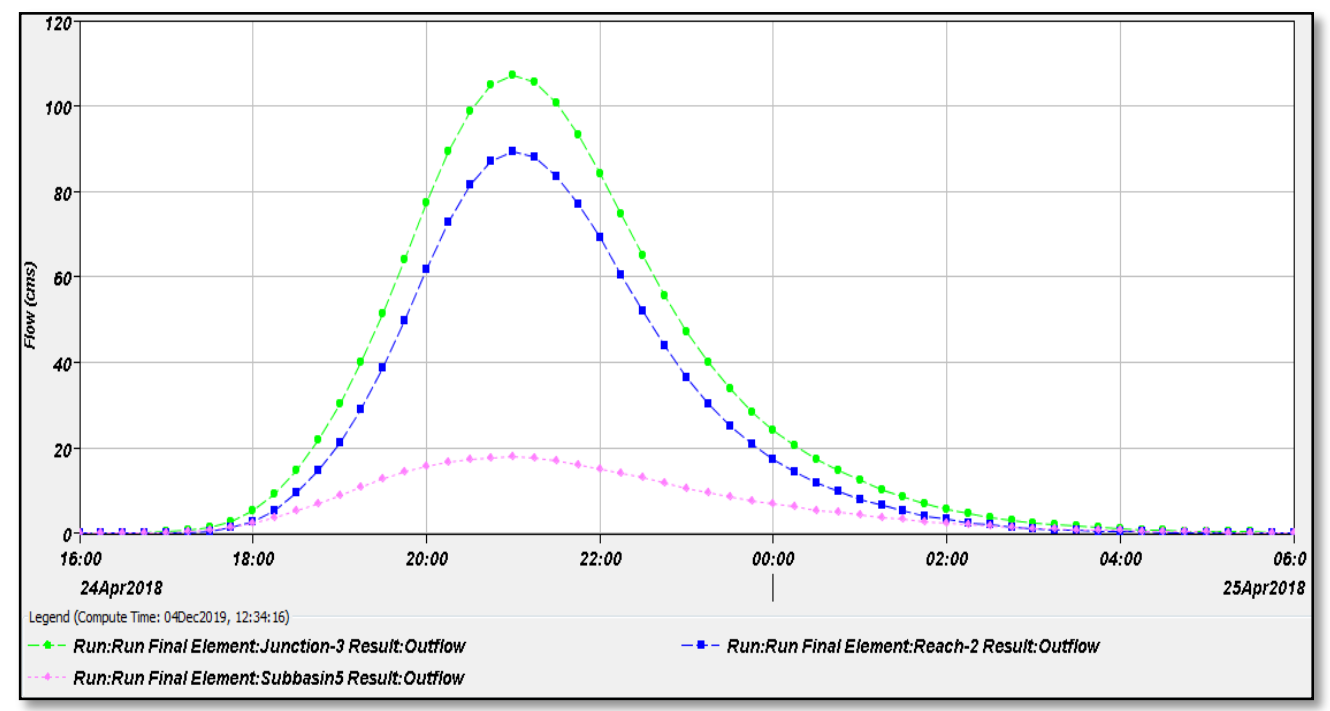

Fig. (13). Computed runoff hydrograph for Wadi Degla (rural case).

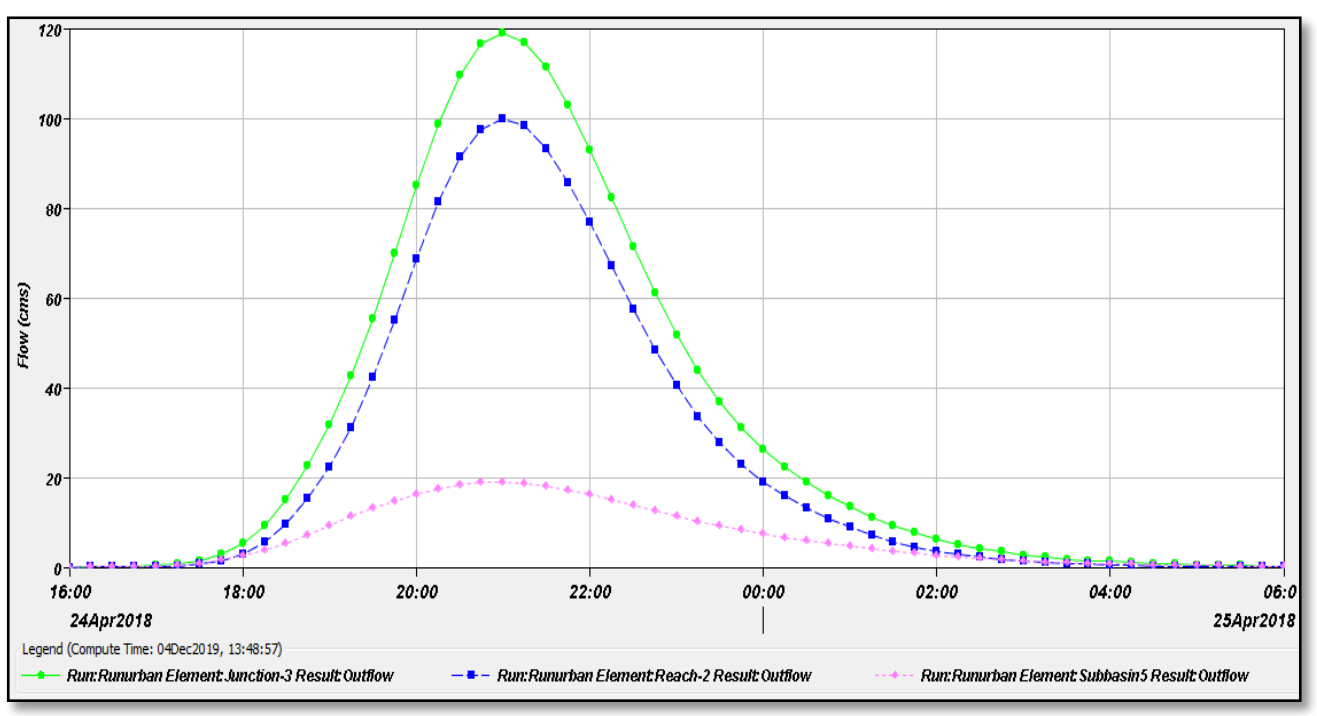

Fig. (14). Computed runoff hydrograph for Wadi Degla (urban case).

Egyptian J. Desert Res., 70, No. 1, $25-57$ (2020) 


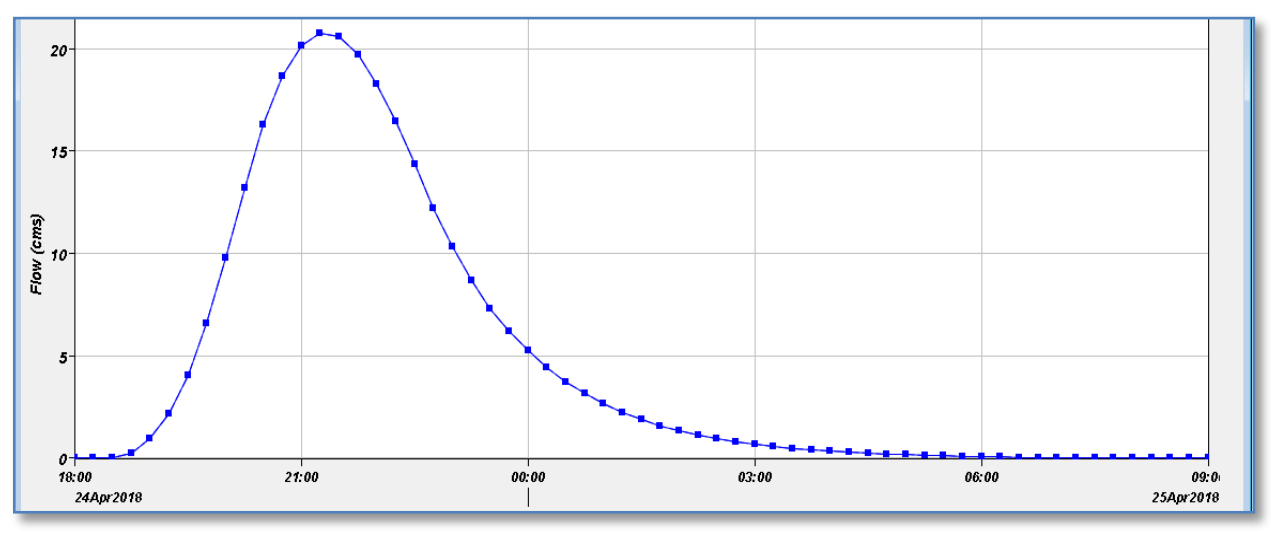

Fig. (15). Computed runoff hydrograph for Wadi El-Halazouni (rural case).

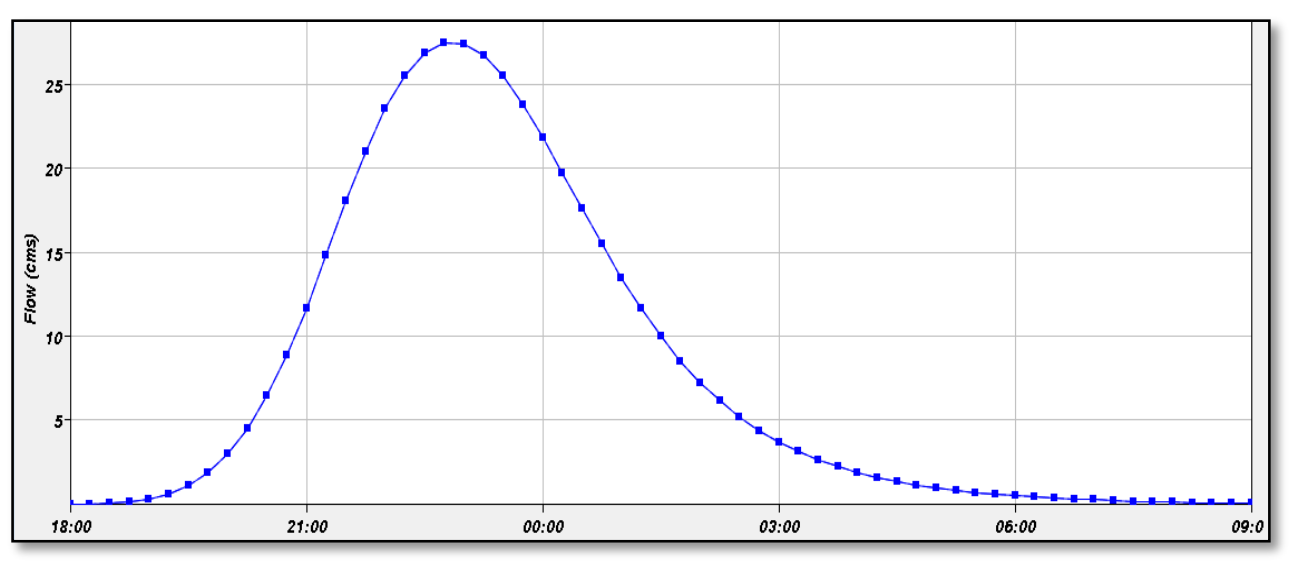

Fig. (16). Computed runoff hydrograph for Wadi El-Halazouni (urban case).

From the above tables and figures, the following can be concluded for each wadi:

\section{Wadi Degla}

- In case of rural area (1984), the outlet of the Wadi receives a peak discharge equals $107.20 \mathrm{~m}^{3} / \mathrm{sec}$ with runoff volume equals to $1434.6 \times 10^{3} \mathrm{~m}^{3}$. For urban case (2018), the peak discharge is 118.80 $\mathrm{m}^{3} / \mathrm{sec}$ with runoff volume equals to $1570.4 \times 10^{3} \mathrm{~m}^{3}$.

- For the two cases (rural and urban), Sub-Basin 2, which is located in the upstream of the wadi having East-West direction gives the maximum discharge $\left(33.50 \mathrm{~m}^{3} / \mathrm{sec}\right)$ in rural case with runoff volume equals to $296.6 \times 10^{3} \mathrm{~m}^{3}$. In urban case the maximum discharge is $35.10 \mathrm{~m}^{3} / \mathrm{sec}$ with runoff volume equals to $309.1 \times 10^{3} \mathrm{~m}^{3}$. 
- For rural case, the runoff depth ranges between 4.92 and $15.66 \mathrm{~mm}$. The runoff coefficient varies from 16.73 to $37 \%$. This means that about $37 \%$ of rainfall is transmitted to runoff. In case of urban case, the runoff depth ranges between $5.20 \mathrm{~mm}$ and $18.65 \mathrm{~mm}$. The runoff coefficient varies from 16.88 to $44.05 \%$, which means that about $44 \%$ of rainfall is transmitted to runoff.

- From the field investigation, it is noticed that the Egyptian Government begins to construct two detention dams along the main trunk of the wadi (Fig. 17), in order to protect the infrastructures in the Delta of the wadi from the runoff hazard.

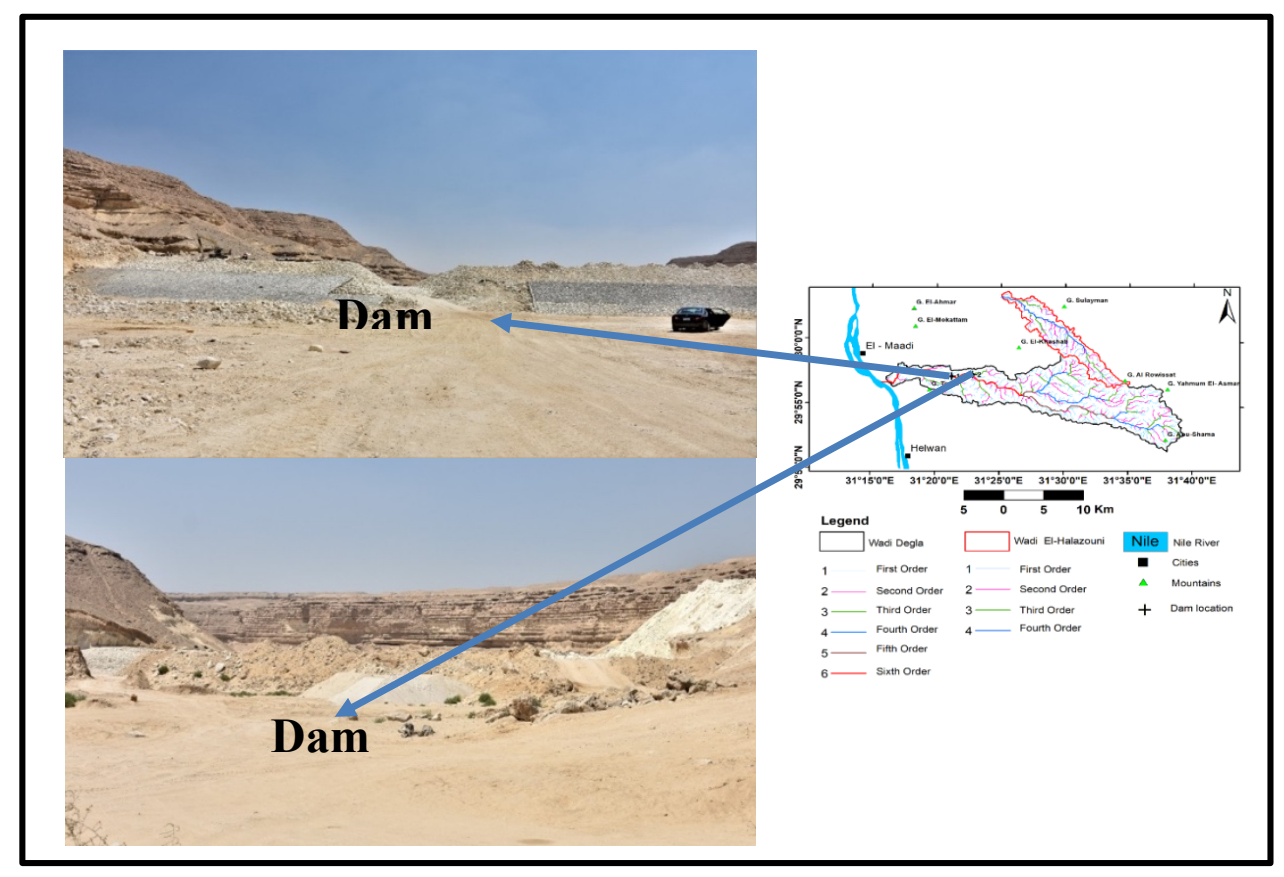

Fig. (17). Location map of the detention Dam1 in Wadi Degla.

\section{Wadi El-Halazouni}

The area of Wadi El Halazouni is relatively small $\left(47.92 \mathrm{~km}^{2}\right)$, so it was treated as one basin. For the rural case (1984), the outlet of the Wadi receives a peak discharge of $20.8 \mathrm{~m}^{3} / \mathrm{sec}$ with runoff volume equals to $252.3 \times 10^{3} \mathrm{~m}^{3}$. For the urban case (2018) the amount of runoff is $27.5 \mathrm{~m}^{3} / \mathrm{sec}$ and the runoff volume is $416.7 \mathrm{~m}^{3}$. The runoff coefficient is $15.7 \%$ in rural area, while it increases to $25.91 \%$ in urban area. This means that for urban area, about $26.0 \%$ of rainfall is transmitted to runoff, with an increase equals to $39.4 \%$ than the rural case.

Egyptian J. Desert Res., 70, No. 1, 25-57 (2020) 
According to the model results, the study area is subjected to an increase in urban area between the period 1984 and 2018. Urbanization leads to an increase of the impervious areas, changes the hydrologic cycle and reduces infiltration rates. This is very clear in the results of rainfall- runoff modeling, where the runoff depth for the urban case is found more than the rural case. This indicates that more urbanization results more runoff. The runoff volume increased from 1984 to 2018, with ratio equals to $8.6 \%$ (Wadi Degla) and $39.4 \%$ (Wadi El-Halazouni). It can be noticed that the difference in runoff volume between 1984 and 2018 in Wadi El-Halazouni is enormous (about 39\%), this is due to the high development and the huge amount of buildings during this period of time. In Wadi Degla, the condition is different, where about $60 \%$ of the area of the wadi is treated as protector area and consequently it is prohibited to make any urban communities.

\section{CONCLUSIONS AND RECOMMENDATIONS}

From the abovementioned results and discussions, the following points can be concluded:

- From the morphometric analysis, it can be noticed that Wadi Degla and Wadi El- Halazouni have nearly the same characteristics. The Wadis are elongated in shape and have lower peak runoff of longer duration over the area.

- The historical data for the last 66 years show that the maximum monthly rainfall (40 mm at April 2018) may occur every 67 year.

- The maximum number of occurrences of maximum monthly rainfall is 22 years, ranges between 10.0 and $15.0 \mathrm{~mm}$, which represents about $33 \%$ of the collected data.

- The authors applied the hydrological model based on two different cases. The first case treats the hydrologic conditions of the area in 1984, before any urbanization where the whole area was rural. The second case represents the hydrologic conditions in 2018, where the urban area represents about 30.3\% in Wadi El-Halazouni and 16.5\% in Wadi Degla (Wadi Degla is declared as a protector area since 1999.

- The values of curve number increase with urbanization, which leads to more runoff.

- In Wadi El-Halazouni, urbanization plays an important role in the increases of the runoff from $15.7 \%$ in 1984 to $25.91 \%$ in 2018 . Urban run-off increases significantly due to the increase in impervious ratio and reduced drainage network. In other words, more urbanization results more runoff.

- From the abovementioned results and discussions, the followings items are recommended: 
- Estimation of storm runoff is important for the effective design of road structures.

- Hydrological and geological studies should be carried out before the construction of any new settlements in this area.

- In Wadi El-Halazouni, it is recommended to conserve the runoff water resulting from the storm through pipe line network under the asphaltic roads leading to water tanks.

- In Wadi Degla, the government starts to build a group of successive detention dams along the main trunk of the Wadi, especially in the protector area, to conserve the runoff water and protect the infrastructure in the Delta of the Wadi.

\section{REFERENCES}

ARC/Map Software (1999-2014). ESRI ARC/Map 10.2.2, copyright 19992014, ESRI Inc.

Barron, T. (1907). In: "The Topography and Geology of the District Between Cairo and Suez, Egypt". Surv. Dept., 133 pp.

Brook, R.J. (1986). In: "The Fascination of Statistics", CRC Press, New York.

Chorely, R.J. (1969). In: "Introduction to Physical Hydrology", Methuen and Co. Ltd., Suffolk, 211 pp.

Chow, V.T., D.R. Maidment and L.W. Mays (1988). In: "Applied Hydrology". McGraw-Hill, New York, USA.

CONOCO and the Egyptian general petroleum company (EGPC) (1987). Geological maps of Egypt" scale 1:500000, NH 36 NW Cairo and NH 36 SW Beni Suef.

EGSA (1991-1997). Egyptian General Survey Authority. Topographic maps of Egypt scale, 1: 50000.

EMA (1949-2018). Egyptian Meteorological Authority. Cairo, Egypt. Available online at: www.nwp.gov.eg/

Granato, G.E. (2010). In: "Methods for Development of Planning-level Estimates of Storm Flow at Unmonitored Sites in the Conterminous United States". Washington, D.C., U.S. Department of Transportation, Federal Highway Administration.

GSMAP. https://sharaku.eorc.jaxa.jp/GSMaP/index.htm

Hagget, P. (1956). In: "Locational Analysis in Human Geography". Edward Arnold Ltd., London, 339 pp.

HEC-HMS (2010). Hydrologic modeling system HEC-HMS, version 4. US Army Corps of Engineers, Institute for Water Resources, Hydrologic Engineering Center, Davis, California.

Horton, R.E. (1932). In: "Drainage basin characteristics" Trans Am Geophys Union, 13: 350- 361.

Egyptian J. Desert Res., 70, No. 1, $25-57$ (2020) 
Horton, R.E. (1945). Erosional developments of streams and their drainage basins-hydrophysical approach to quantitative morphology. Geol. Soc. Am. Bull., 56: 275-370.

McCullagh, P. (1978). In: "Modern Concept in Geomorphology". Oxford University Press, UK.

Melton, M.E. (1957). An analysis of the relations among elements of climate, surface properties and geomorphology. Project NR 389-042 Tech. Report II, Department of Geology, Columbia Univ., R. Branch, New York, USA, 34 pp.

Military Survey (2008-2009). Topographic maps of Egypt, scale 1:25000.

Miller, V.C. (1953). A quantitative geomorphic study of drainage basin characteristics in Clinsh mountain area, Virginia and Tennesse. Project no. 389-042, Technical report 3, Columbia University, New York, USA.

Mockus, V. (1957). Use of storm and watershed characteristics in synthetic hydrograph analysis and application. Annual meeting of AUG Pacific Southwest Region, Washington, DC, USA.

Morisawa, M.E. (1957). Accuracy of determination of stream lengths from topographic maps. Ame. Geophys. Union Trans., 88 (1): 86-88, Washington.

Moustafa, A and A. Abd-Allah (1991). Structural setting of the central part of the Cairo-Suez district. M.E.R.C. Ain Shams Univ., Earth Sci., 5: 133-145.

Mueller, J.E. (1968). An introduction to the hydraulic and topographic sinuosity indexes. Ann. Ass. Am. Geol., 58: 371-385.

Osrborn, J.F. (1970). Drainage density on drift-covered basins. Journal of the Hydraulics Division, 96 (1): 183-192.

Ponce, V.M. (1989). In: "Engineering Hydrology, Principle and Practices". Prentice-Hall, New Jersey, USA.

Said, R. (1962). In: "The Geology of Egypt". Amsterdam, Elsevier.

Said, R. (1990). In: "The Geology of Egypt". Amsterdam, Elsevier.

Schumm, S.A. (1956). Evolution of drainage systems and slopes in badlands at Perth Amboy, New Jersy. Bulletin Geological Society America, 67: 597-646.

Schumm, S.A. (1965). Geomorphic research; Applications to erosion control in New Zealand". Soil and Water (Soil Conservation and Rivers Control Council), 1: 21-24.

Şen, Z., A.H. Khiyami and S.G. Al-Harthy (2012). Flash flood inundation map preparation for wadis in arid regions. Arabian J. Geosci. https://doi.org/10.1007/ s12517-012-0614-6.

Shukri, N.M. (1954). On cylindrical structures and colouration of Gebel Ahmar near Cairo, Egypt. Bull. Fac. Sci., Cairo Univ., 32: 1-23.

SCS (1986). Soil Conservation Service, In: "Hydrology Guide for use in Watershed Planning". SCS National Engineering Handbook. Section 
4: Hydrology. US Department of Agriculture, Soil Conservation Service, Engineering Division, Washington.

Singh, S.A. and M. Sharma (2008). Hypsometric integral estimation methods and its relevance on erosion status of North-Western Lesser Himalayan Watersheds. Water Resources Management, 22 (11): 1545-1560.

Smart, J.S. (1972). In: "Channel Networks Advanced in Hydro Sciences". Vol. 8, p. 305-346.

Strahler, A.N. (1952). Hypsometric analysis of erosional topography. Bulletin of the Geological Society of America, 63: 1117-1142.

Strahler, A.N. (1957). Quantitative analysis of watershed geomorphology. Transactions of the American Geophysical Union, 38: 913-920.

Udayashankara, T.H., B.M. Sadashiva Murthy and M. Madhukar (2016). Impact of climate change on rainfall pattern and reservoir level. Journal of Water Resource Engineering and Management, 3 (1): 1014.

UNDP, GEF and Cairo University (2008). Vegetation dynamics assisted hydrological analysis for Wadi Degla. Developing renewable groundwater resources in arid land, pilot case. The Eastern Desert of Egypt.

Veissman, W. and G.L. Lewis (2003). In: "Introduction to Hydrology". $5^{\text {th }}$ Ed., Prentice Hall: Upper Saddle River, NJ. 612 pp.

Zerger, A. and D.I. Smith (2003). Impediments to using GIS for real-time disaster decision support. Comput. Environ. Urban Syst., 27: 123141.

Egyptian J. Desert Res., 70, No. 1, $25-57$ (2020) 


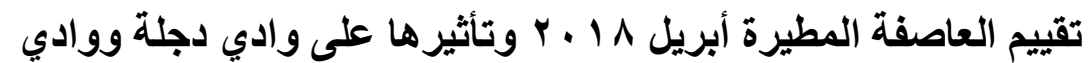

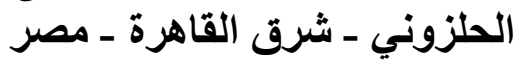

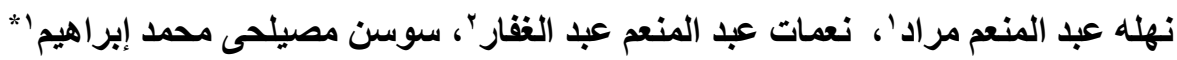

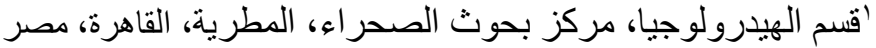

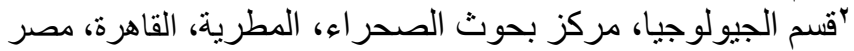

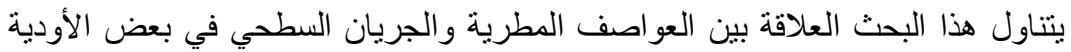

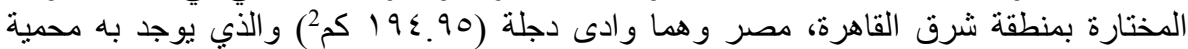

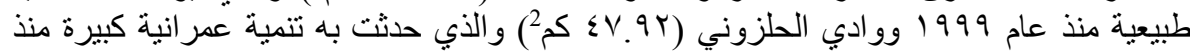

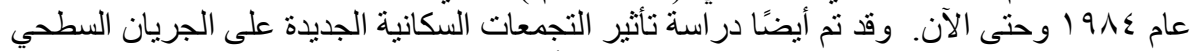

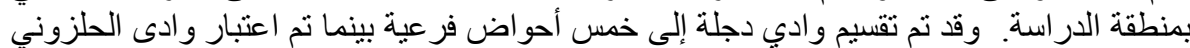

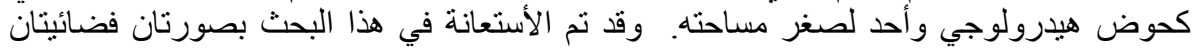

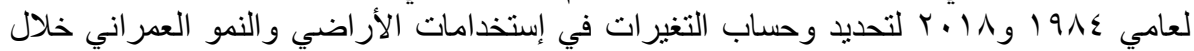

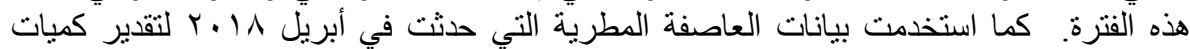

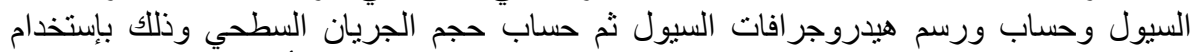

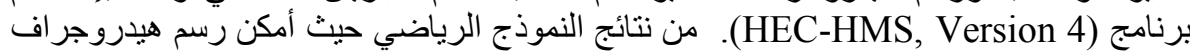

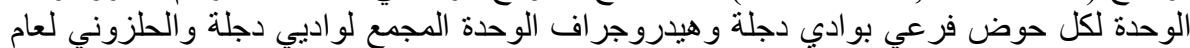

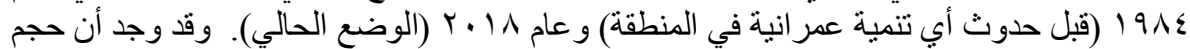

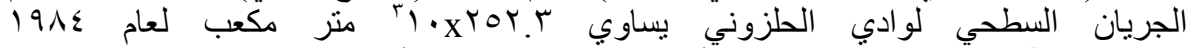

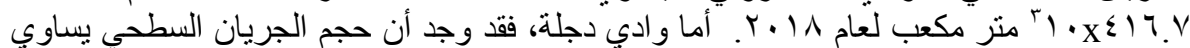

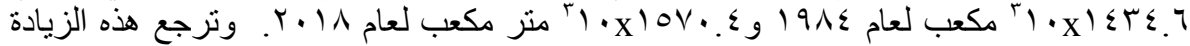

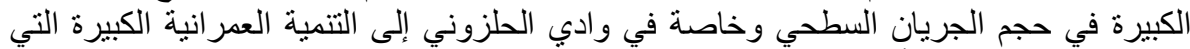

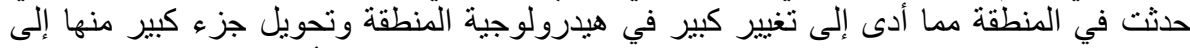

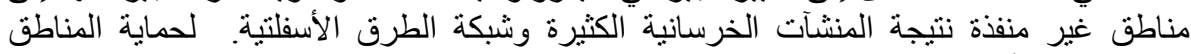

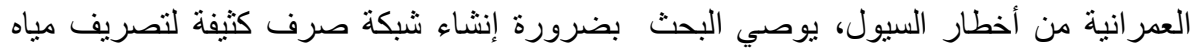

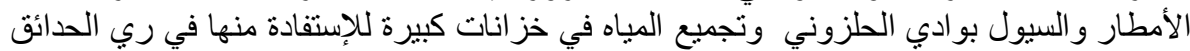

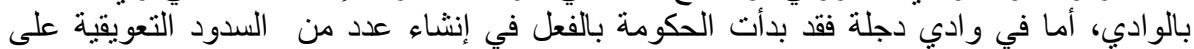
المجرى الرئيسي للوادي وذللك لحماية المنشآت الموجودة في دلتا الوادي من خطر الئي السيول الفجائية. 